\title{
Variability of mineral dust deposition in the western Mediterranean basin and south-east of France
}

\author{
Julie Vincent ${ }^{1}$, Benoit Laurent ${ }^{1}$, Rémi Losno ${ }^{1, a}$, Elisabeth Bon Nguyen $^{1}$, Pierre Roullet $^{2}$, Stéphane Sauvage $^{3}$, \\ Servanne Chevaillier ${ }^{1}$, Patrice Coddeville ${ }^{3}$, Noura Ouboulmane ${ }^{1}$, Alcide Giorgio di Sarra ${ }^{4}$, Antonio Tovar-Sánchez ${ }^{5,6}$, \\ Damiano Sferlazzo $^{4}$, Ana Massanet ${ }^{6}$, Sylvain Triquet ${ }^{1}$, Rafael Morales Baquero ${ }^{7}$, Michel Fornier ${ }^{8}$, Cyril Coursier ${ }^{9}$, \\ Karine Desboeufs $^{1}$, François Dulac ${ }^{10}$, and Gilles Bergametti ${ }^{1}$ \\ ${ }^{1}$ Laboratoire Interuniversitaire des Systèmes Atmosphériques (LISA), UMR7583 CNRS, Université Paris Denis Diderot, \\ Université Paris-Est Créteil, Institut Pierre-Simon Laplace, Paris, France \\ ${ }^{2}$ Ingénierie, Conseil, Assistance technique, Recherche, Étude (ICARE Ingénierie), Paris, France \\ ${ }^{3}$ Département Sciences de l'Atmosphère et Génie de l'Environnement (SAGE), Mines Douai, 59508, Douai, France \\ ${ }^{4}$ Laboratory for Earth Observations and Analyses (ENEA), Santa Maria di Galeria, Italy \\ ${ }^{5}$ Andalusian Marine Science Institute (ICMAN, CSIC), Cádiz, Spain \\ ${ }^{6}$ Institut Mediterrani d'Estudis Avançats (IMEDEA-CSIC/UIB), Balearic Island, Spain \\ ${ }^{7}$ Departamento Ecologia, Universitad Granada, Granada, Spain \\ ${ }^{8}$ Mediterranean Institute of Oceanography (MIO), UMR7294 CNRS, UMR235 IRD, Université Aix-Marseille, \\ Université du Sud Toulon-Var, Marseille, France \\ ${ }^{9}$ Parc national des Ecrins, Le Casset, France \\ ${ }^{10}$ Laboratoire des Sciences du Climat et de l'Environnement (LSCE), UMR 8212 CEA-CNRS-UVSQ, \\ Institut Pierre-Simon Laplace, Gif-sur-Yvette, France \\ ${ }^{a}$ present address: Institut de Physique du Globe de Paris (IPGP), UMR7154 CNRS, Sorbonne Paris Cité, \\ Université Paris Denis Diderot, Paris, France
}

Correspondence to: J. Vincent (julie.vincent@lisa.u-pec.fr)

Received: 25 September 2015 - Published in Atmos. Chem. Phys. Discuss.: 10 December 2015

Revised: 19 April 2016 - Accepted: 27 June 2016 - Published: 18 July 2016

\begin{abstract}
Previous studies have provided some insight into the Saharan dust deposition at a few specific locations from observations over long time periods or intensive field campaigns. However, no assessment of the dust deposition temporal variability in connection with its regional spatial distribution has been achieved so far from network observations over more than 1 year. To investigate dust deposition dynamics at the regional scale, five automatic deposition collectors named CARAGA (Collecteur Automatique de Retombées Atmosphériques insolubles à Grande Autonomie in French) have been deployed in the western Mediterranean region during 1 to 3 years depending on the station. The sites include, from south to north, Lampedusa, Majorca, Corsica, Frioul and Le Casset (southern French Alps). Deposition measurements are performed on a common weekly period at the five sites. The mean dust deposition fluxes are higher close to
\end{abstract}

the northern African coasts and decrease following a southnorth gradient, with values from $7.4 \mathrm{~g} \mathrm{~m}^{-2}$ year $^{-1}$ in Lampedusa $\left(35^{\circ} 31^{\prime} \mathrm{N}, 12^{\circ} 37^{\prime} \mathrm{E}\right)$ to $1 \mathrm{~g} \mathrm{~m}^{-2}$ year $^{-1}$ in Le Casset $\left(44^{\circ} 59^{\prime} \mathrm{N}, 6^{\circ} 28^{\prime} \mathrm{E}\right)$. The maximum deposition flux recorded is of $3.2 \mathrm{~g} \mathrm{~m}^{-2} \mathrm{wk}^{-1}$ in Majorca with only two other events showing more than $1 \mathrm{~g} \mathrm{~m}^{-2} \mathrm{wk}^{-1}$ in Lampedusa, and a maximum of $0.5 \mathrm{~g} \mathrm{~m}^{-2} \mathrm{wk}^{-1}$ in Corsica. The maximum value of $2.1 \mathrm{~g} \mathrm{~m}^{-2}$ year $^{-1}$ observed in Corsica in 2013 is much lower than existing records in the area over the 3 previous decades (11-14 $\mathrm{g} \mathrm{m}^{-2}$ year $\left.^{-1}\right)$. From the 537 available samples, 98 major Saharan dust deposition events have been identified in the records between 2011 and 2013. Complementary observations provided by both satellite and air mass trajectories are used to identify the dust provenance areas and the transport pathways from the Sahara to the stations for the studied period. Despite the large size of African dust plumes detected 
by satellites, more than $80 \%$ of the major dust deposition events are recorded at only one station, suggesting that the dust provenance, transport and deposition processes (i.e. wet vs. dry) of dust are different and specific for the different deposition sites in the Mediterranean studied area. The results tend to indicate that wet deposition is the main form of deposition for mineral dust in the western Mediterranean basin, but the contribution of dry deposition (in the sense that no precipitation was detected at the surface) is far from being negligible, and contributes 10 to $46 \%$ to the major dust deposition events, depending on the sampling site.

\section{Introduction}

A reliable estimation of the dust content in the atmosphere and of its variability in space and time is needed to assess desert dust impacts on the Earth system. The most convenient tools to conduct this assessment are atmospheric dust models in which the atmospheric cycle of mineral dust is represented: dust emissions by wind erosion on arid and semiarid regions; atmospheric transport, which is strongly controlled by the meteorological situations; and deposition of dust along their atmospheric path by dry or wet processes. A validation of the closure of the dust budget in atmospheric dust models needs to quantify precisely the amount of emitted dust, the atmospheric dust load and the dry and wet deposited dust mass (Bergametti and Fôret, 2014).

Significant progress has been made on dust emission modelling during the last 2 decades (Shao et al., 1993; Marticorena and Bergametti, 1995; Alfaro and Gomes, 2001; Shao, 2004; Marticorena, 2014) and on the dust source monitoring, especially by using satellite observations (Brooks and Legrand, 2000; Prospero et al., 2002; Washington et al., 2003; Schepanski et al., 2012). However, quantitative estimates of dust emissions in atmospheric models are still affected by large uncertainties (Zender et al., 2004; Textor et al., 2006; Huneeus et al., 2011), mainly because a direct and quantitative validation of soil dust emissions at a large scale remains not possible. The spatial distribution and temporal variability of atmospheric dust content has also been significantly improved through the development of aerosol products from spaceborne (e.g. Moulin et al., 1997; Torres et al., 2002; Shi and Cressie, 2007; Remer et al., 2008; Nabat et al., 2013), ground-based (Holben et al., 2001) and shipborne (Smirnov et al., 2011), remote-sensing instruments. Presently, large available data sets of aerosol optical depth (AOD) have been widely and mostly used to validate dust atmospheric contents simulated by 3-D models at global (e.g. Chin et al., 2002; Ginoux and Torres, 2003; Huneeus et al., 2011) or regional scales (e.g. Cautenet et al., 2000).

Atmospheric dust particles are removed from the atmosphere by dry and wet depositions processes (Duce and Tindale, 1991; Schulz et al., 2012). These two sinks, which counterbalance dust emissions on the global scale, control the atmospheric lifetime of dust particles (Bergametti and Fôret, 2014). However, rather little attention has been paid to dust deposition and few experiments were dedicated to test dust deposition schemes against in situ data. There is an urgent need for further research and measurements of dust deposition. Dust models are mainly validated against proxies for the atmospheric dust load, e.g. AOD, concentrations, dust vertical profiles or combinations of these. However, at least two of the terms emissions, dust load and deposition, need to be documented to close the dust mass budget.

In this paper, we will present the results over a 3-year period concerning atmospheric mass deposition measurements associated with Saharan dust transport over the western Mediterranean Basin. The main goal of the sampling strategy is to provide data that can be used directly to test the dust mass budget in dust transport model. This data set of Saharan dust deposition in the western Mediterranean region can also be used to identify the transport patterns and the provenance of the dust. To do that, deposition measurements are coupled with satellite observations and air mass trajectories.

\section{Deposition measurement in the Mediterranean region}

Atmospheric deposition fluxes have been measured in the Mediterranean region during the last 50 years. Table 1 gathers the direct deposition measurements performed both close to Saharan dust source areas and far away on both sides of the Mediterranean basin. Most of these deposition mass fluxes were obtained directly by weighting the deposited mass, the others being derived from aluminum deposition measurements assuming that this element contributes about 7 to $8 \%$ of the total dust mass (e.g. Guieu et al., 2002). Note that dust deposition can be also estimated indirectly based on the measurements of atmospheric aerosol concentrations and assuming dust dry deposition velocity and scavenging ratio (e.g. Le Bolloch et al., 1996).

Dust deposition measurements close to the North African dust sources are rare: dust deposition fluxes were only measured in Morocco, Tunisia and Libya. The deposition samples from Tunisia and Morocco (Guieu et al., 2010) were collected at sampling sites located along the Mediterranean coasts and indicate deposition fluxes ranging from 7 to $23 \mathrm{~g} \mathrm{~m}^{-2}$ year ${ }^{-1}$. Dust deposition sampled in Libya (O'Hara et al., 2006), in 24 stations located from the north to the south of the country, provide significantly higher deposition fluxes, ranging from 40 to $420 \mathrm{~g} \mathrm{~m}^{-2}$ year $^{-1}$.

In the Mediterranean basin itself, dust deposition fluxes exhibit a large spatial variability ranging over more than 1 order of magnitude, from 2 to more than $27 \mathrm{~g} \mathrm{~m}^{-2}$ year $^{-1}$ in the western basin and from 4 to $\sim 100 \mathrm{~g} \mathrm{~m}^{-2}$ year $^{-1}$ in the eastern basin (Table 1), but also a strong inter-annual vari- 
Table 1. Dust deposition fluxes measured in the Mediterranean basin and northern Africa. ${ }^{\text {a }}$ Sampling performed in different places and periods, ${ }^{\mathrm{b}}$ in different places, ${ }^{\mathrm{c}}$ assuming $\mathrm{Al}$ is $7.1 \%$ of total dust (Guieu et al., 2002).

\begin{tabular}{|c|c|c|c|c|c|c|}
\hline Region & Location & Period & Duration & $\begin{array}{l}\text { Deposition flux } \\
\left(\mathrm{g} \mathrm{m}^{-2} \text { year }^{-1}\right)\end{array}$ & Comments & Reference \\
\hline \multirow[t]{14}{*}{$\begin{array}{l}\text { Western } \\
\text { Mediterranean }\end{array}$} & $\begin{array}{l}\text { Cap Ferrat and three } \\
\text { sites }\end{array}$ & 2003-2007 & 4 years $^{\mathrm{a}}$ & 11.4 & Insoluble & Ternon et al. (2010) \\
\hline & $\begin{array}{l}\text { SE France and NW } \\
\text { Corsica }\end{array}$ & & & & & \\
\hline & $\begin{array}{l}\text { Cap Bear, } \\
\text { SW France }\end{array}$ & 2001-2002 & 12 months & $10.6^{\mathrm{c}}$ & Bulk & Guieu et al. (2010) \\
\hline & $\begin{array}{l}\text { Capo Cavallo, } \\
\text { NW Corsica }\end{array}$ & 1985-1986 & 12.5 months & $12.5^{\mathrm{c}}$ & Bulk & Bergametti et al. (1989) \\
\hline & & 1986-1987 & 20 months & 9.7 & Bulk & Remoudaki (1990) \\
\hline & $\begin{array}{l}\text { Three inland sites, } \\
\text { Corsica }\end{array}$ & 1984-1994 & 10 years $^{b}$ & $4-26$ & Bulk & $\begin{array}{l}\text { Loÿe-Pilot and Martin } \\
\text { (1996) }\end{array}$ \\
\hline & $\begin{array}{l}\text { Ostriconi, } \\
\text { N Corsica }\end{array}$ & 2001-2002 & 12 months & $27.4^{\mathrm{c}}$ & Bulk & Guieu et al. (2010) \\
\hline & $\begin{array}{l}\text { Pirio, } \\
\text { NW Corsica }\end{array}$ & 1995-1997 & 27 months & $2-4^{c}$ & Bulk & Ridame et al. (1999) \\
\hline & & 1999-2000 & 13 months $^{\mathrm{a}}$ & $9-14^{\mathrm{c}}$ & Bulk & Loÿe-Pilot et al. (2001) \\
\hline & $\begin{array}{l}\text { Capo Carbonara, } \\
\text { SE Sardinia }\end{array}$ & 1990-1992 & 19 months & $12.8^{\mathrm{c}}$ & Bulk & Guerzoni et al. (1999) \\
\hline & $\begin{array}{l}\text { Montseny, } \\
\text { NE Spain }\end{array}$ & 1983-1994 & 11 years & $\begin{array}{l}5.2 \\
\text { Dust rains only }\end{array}$ & Bulk & Avila et al. (1997) \\
\hline & $\begin{array}{l}\text { Palma de, } \\
\text { Baleares }\end{array}$ & 1982-2003 & 22 years & $\begin{array}{l}\sim 14 \\
\text { Dust rains only }\end{array}$ & Bulk & Fiol et al. (2005) \\
\hline & $\begin{array}{l}\text { Campo de Gibraltar } \\
\text { S Spain }\end{array}$ & $1982-1983$ & 12 months & $22.8^{\mathrm{c}}$ & $\begin{array}{l}\text { Soluble } \\
+ \text { Insoluble }\end{array}$ & $\begin{array}{l}\text { Usero and Gracia } \\
\text { (1986) }\end{array}$ \\
\hline & $\begin{array}{l}\text { Lanjaron, } \\
\text { SE Spain }\end{array}$ & 2001-2002 & 23 months & 11.1 & Bulk & $\begin{array}{l}\text { Morales-Baquero et al. } \\
\text { (2006) }\end{array}$ \\
\hline \multirow[t]{8}{*}{$\begin{array}{l}\text { Eastern } \\
\text { Mediterranean }\end{array}$} & $\begin{array}{l}\text { Erdemli, } \\
\text { SE Turkey }\end{array}$ & 1991-1992 & 16 months & 13.0 & Bulk & Kubilay et al. (2000) \\
\hline & $\begin{array}{l}\text { Akkuyu, } \\
\text { SE Turkey }\end{array}$ & 2001-2002 & 12 months & $10.1^{\mathrm{c}}$ & Bulk & Guieu et al. (2010) \\
\hline & $\begin{array}{l}\text { Six sites, } \\
\text { Crete }\end{array}$ & 1988-1994 & 6 years & $11-23$ & Bulk & $\begin{array}{l}\text { Mattson and Nihlén } \\
\text { (1994) }\end{array}$ \\
\hline & $\begin{array}{l}\text { Seven sites, } \\
\text { Crete }\end{array}$ & 1988-1990 & 34 month & $10-100$ & Bulk & Pye (1992) \\
\hline & $\begin{array}{l}\text { Finokalia, } \\
\text { NE Crete }\end{array}$ & 2001-2002 & 12 months & $8.8^{\mathrm{c}}$ & Bulk & Guieu et al. (2010) \\
\hline & $\begin{array}{l}\text { Cavo Greco, } \\
\text { SE Cyprus }\end{array}$ & 2001-2002 & 12 months & $4.2^{\mathrm{c}}$ & Bulk & Guieu et al. (2010) \\
\hline & $\begin{array}{l}\text { Mytilene, } \\
\text { Lesbos }\end{array}$ & 2001-2002 & 12 months & $5.4^{\mathrm{c}}$ & Bulk & Guieu et al. (2010) \\
\hline & Israel & 1965-1995 & $\mathrm{a}$ & $30-90$ & Insoluble & $\begin{array}{l}\text { Ganor and Foner } \\
\text { (2001) }\end{array}$ \\
\hline \multirow[t]{4}{*}{$\begin{array}{l}\text { Northern } \\
\text { Africa }\end{array}$} & $\begin{array}{l}\text { Alexandria, } \\
\text { N Egypt }\end{array}$ & 2001-2002 & 8.5 months & $20.3^{\mathrm{c}}$ & Bulk & Guieu et al. (2010) \\
\hline & $\begin{array}{l}14 \text { inland sites, } \\
\text { N Libya }\end{array}$ & 2000-2001 & 12 months & $\begin{array}{l}58 \\
(<20 \mu \mathrm{m} \text { only })\end{array}$ & Bulk & O'Hara et al. (2006) \\
\hline & $\begin{array}{l}\text { Cap Spartel, } \\
\text { N Morocco }\end{array}$ & 2001-2002 & 12 months & $7.2^{\mathrm{c}}$ & Bulk & Guieu et al. (2010) \\
\hline & $\begin{array}{l}\text { Mahdia, } \\
\text { E Tunisia }\end{array}$ & 2001-2002 & 12 months & $23.3^{\mathrm{c}}$ & Bulk & Guieu et al. (2010) \\
\hline
\end{tabular}


ability with fluxes ranging from 4 to $26 \mathrm{~g} \mathrm{~m}^{-2} \mathrm{year}^{-1}$ in Corsica over an 11-year period (Loÿe-Pilot and Martin, 1996). It must be emphasised that most of the temporal variability at a given site is due to the occurrence of very intense but rare events with fluxes of several $\mathrm{g} \mathrm{m}^{-2}$ that dominate the annual deposition flux when they occur (see for instance Bergametti et al., 1989; Loÿe-Pilot and Martin, 1996; Fiol et al., 2005).

These measurements provide a picture of the dust deposition in the Mediterranean basin, the heterogeneity of data does not allow one to precisely investigate the spatial and temporal variabilities of the dust deposition fluxes. Indeed, most of these dust deposition measurements were performed either in one site during a long time period (e.g. data sets obtained in Corsica between 1984 and 1994 by Loÿe-Pilot and Martin, 1996, or in Crete between 1988 and 1994 by Pye, 1992, and Mattson and Nihlén, 1994), or on a network of several stations but during a much shorter time period. Moreover, the dust deposition fluxes were generally not measured with the same devices. This complicates the comparison of the data collected at the different sites.

Thus, a better understanding of the dust deposition in the Mediterranean basin, and especially of its spatial and temporal variability, requires measurements performed simultaneously at several stations and with similar devices during a long-time period. With this objective, a new deposition sampler was developed for use at remote sites in full autonomy over several months (Laurent et al., 2015).

\section{Materials and methods}

\subsection{The CARAGA deposition collector}

In order to be able to maintain over a long time period a network to measure dust mass deposition fluxes, our strategy was to sample only the insoluble deposition. This greatly simplifies the design of the collector and the on-site operations. More than $80 \%$ of the total Saharan dust deposition mass in the Mediterranean basin occurs in the form of insoluble material (Guerzoni et al., 1993; Avila et al., 2007). As a consequence, an automatic collector called CARAGA (Collecteur Automatique de Retombées Atmosphériques insolubles à Grande Autonomie) was developed in collaboration between the ICARE Ingénierie Company and the Laboratoire Interuniversitaire des Systèmes Atmosphériques (Fig. 1). The CARAGA was designed to require limited human intervention and to be produced in small series to develop a standardised deposition network in remote areas (Laurent et al., 2015). A collecting open funnel $\left(0.2 \mathrm{~m}^{2}\right)$, fixed on a steel structure at least $2.5 \mathrm{~m}$ above ground level (a.g.l.), allows for the collection of both dry and wet deposition. The funnel vibrates and is rinsed automatically with pure water at the end of a sampling time period to drive down the collected particles on a filter. The online passive filtrating system allows for collecting the particles on one of the filters, which are in-

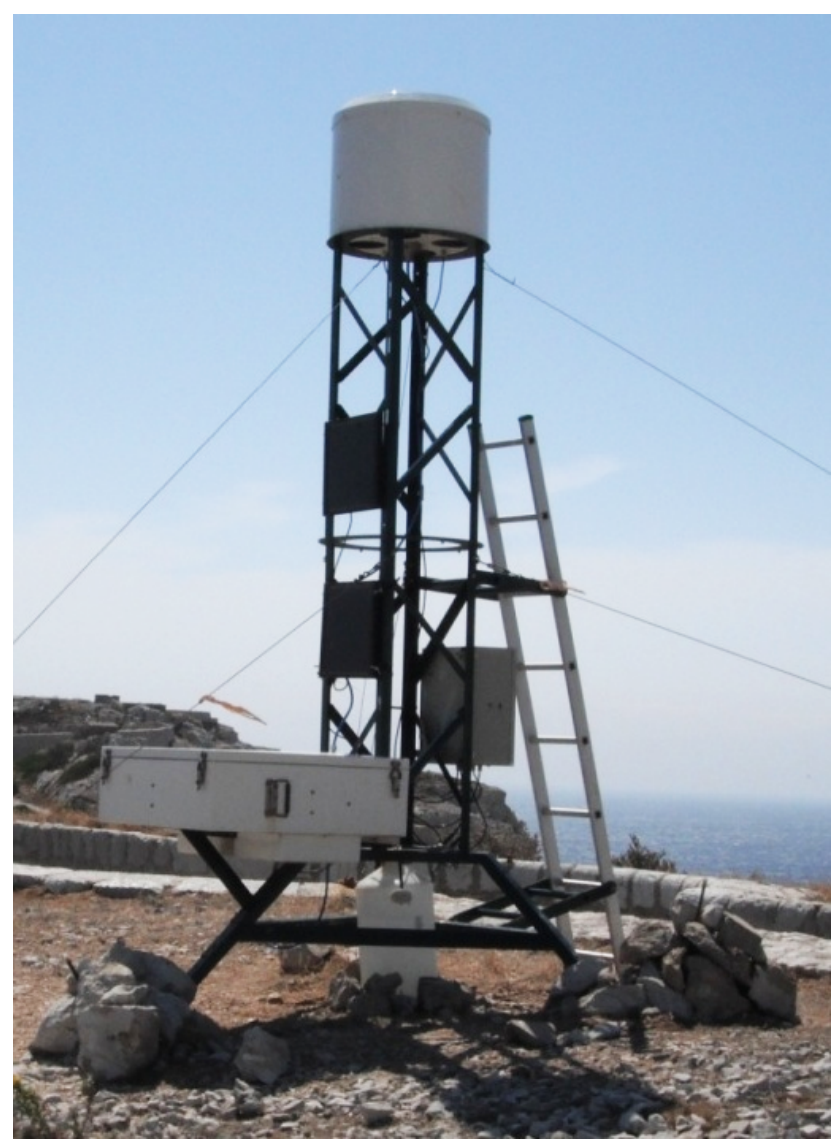

Figure 1. The CARAGA collector operating on Frioul.

stalled in a motorised rotating unit carrying 25 filter holders. A solar panel insures the power supply of the CARAGA. A new filter is set automatically in the sampling position for each sampling step, whose duration can be defined through an electronic interface. The funnel vibration and rinsing can be programmed to operate 2 times before every filter change. The CARAGA system is best suited for the collection of the non-soluble fraction of dust, but it could be used for evaluating other inorganic or organic particles after adapting the sampling and lab protocols. A complete description of the CARAGA collector can be found in Laurent et al. (2015).

\subsection{Implementation of the deposition network}

The deposition network in the western Mediterranean basin is constituted of five CARAGA instruments installed mainly on Mediterranean island coasts (Fig. 2). This network is thought to allow for dust deposition sampling along a southnorth transect, from near the North African coast to the south-east of France, covering about $1050 \mathrm{~km}$ from south to north and $870 \mathrm{~km}$ from west to east. The network is constituted of four island sites and one continental site. The first CARAGA was installed in October 2010 on the small elongated Pomègues Island, which is part of the 
Frioul islands, a $2 \mathrm{~km}^{2}$ archipelago. The Frioul's site is sited in the Gulf of Lion a few $\mathrm{km}$ of Marseille under the influence of natural and anthropogenic air masses. The sampler is at $\sim 45 \mathrm{~m}$ in altitude on the small ridge that crosses the whole island, with a distant from the sea of less than $150 \mathrm{~m}$ from both sides. This site, is also a site of the French Mediterranean Ocean Observing System for the Environment (MOOSE; http://www.moose-network.fr/) instrumented by the Mediterranean Institute of Oceanography. In July 2011, a second collector was installed at Le Casset in the southern French Alps, at $\sim 1850 \mathrm{~m}$ in altitude. This site is one of the 13 sites of the network MERA (Observatoire National de Mesure et d'Evaluation en Zone Rurale de la Pollution Atmosphérique à Longue Distance; http://ce.mines-douai.fr/pages/observatoire-mera/) belonging to EMEP (European Monitoring and Evaluation Program, EMEP; http://www.emep.int/). CARAGA samplers were afterward installed: (i) at $7 \mathrm{~m}$ in altitude and $\sim 70 \mathrm{~m}$ from the sea shore at the Ses Salines lighthouse site on the south-eastern tip of Majorca (http://imedea.uib-csic. es/icg/Faro/), a research site operated by the Institut Mediterrani d'Estudis Avançats (IMEDEA), in July 2011; and (ii) at $38 \mathrm{~m}$ in altitude and $\sim 20 \mathrm{~m}$ from the border of the cliff of the north-western coast of Lampedusa located in the central Mediterranean, at the Global Atmosphere Watch (GAW) regional background station (http://www.lampedusa.enea.it/) operated by the Laboratory for Earth Observations and Analyses of the Agenzia Nazionale per le Nuove Tecnologie, l'Energia e lo Sviluppo Economico Sostenibile (ENEA; supersite of the Chemistry-Aerosol Mediterranean Experiment, ChArMEx (http://charmex.lsce.ipsl.fr) in September 2011. The last CARAGA was installed at $75 \mathrm{~m}$ in altitude and $\sim 300 \mathrm{~m}$ from the sea shore on the northern tip of Cape Corsica, headland of Corsica. It is close to the AERONET sunphotometer station downhill the French Navy semaphore of Ersa and a few kilometres from the Ersa supersite of the ChArMEx program. At the stations, the precipitation amounts are available at least on a daily basis.

\subsection{Sampling and lab protocol}

Atmospheric total (wet + dry) insoluble deposition is collected at the five sampling sites over the period 2011-2013. For this study, a 1-week sampling duration was chosen as a compromise between maximising the opportunity of sampling a single dust plume deposition event and the long autonomy of the collector, i.e. up to 25 sampling weeks. The same sampling duration is programmed at the five sites, with an automatic change of the filter every Thursday at 12:00 UTC. In all, 537 weekly atmospheric deposition samples were collected. At least 1 year of continuous deposition measurements is available from every station, the longest time series being from the Frioul site (January 2011 to December 2013). Depending on the site, the data recovery rate of weekly atmospheric deposition samples ranges from 77 to

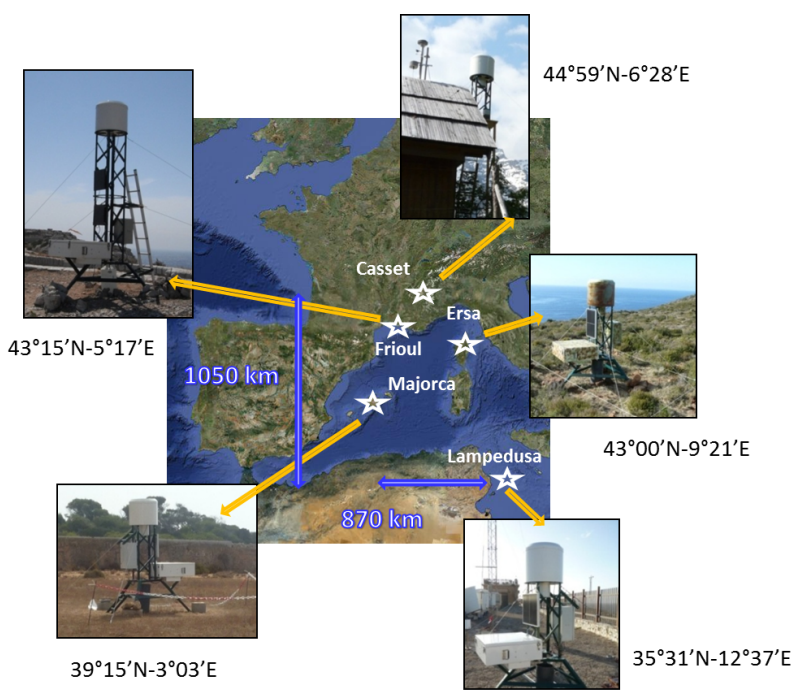

Figure 2. Location of the CARAGA samplers constituting the deposition network deployed in the western Mediterranean basin and southern of France.

$91 \%$ for the sampling period and at least 1 year of continuous measurements is available for each station.

Atmospheric particulate concentrations measured in the Mediterranean suggest that more than $90 \%$ of dust particles mass is in the coarse mode (diameter larger than $1.2 \mu \mathrm{m}$ aerodynamic diameter) (Sciare et al., 2005). Thus, after flow speed tests, we choose to use the AA Millipore cellulose ester filter with a $0.8 \mu \mathrm{m}$ porosity. Moreover, Sheldon (1972) indicated that Millipore cellulose ester filters, with a porosity ranging from 0.45 to $8 \mu \mathrm{m}$, have high percentages of retention of particles of $1 \mu \mathrm{m}$ ranging from 80 to $100 \%$. Prospero (1999) collected atmospheric particles on filters, which were placed in a muffle furnace during $14 \mathrm{~h}$ at $500^{\circ} \mathrm{C}$, the ash residue being assumed to be mineral dust. To determine the mineral mass collected on the filters an ignition and weighing protocol was defined and presented in Laurent et al. (2015). Briefly, it is based on the ignition of the sampled filters following a progressive increase in temperature up to $550^{\circ} \mathrm{C}$ to remove organics and carbon by oxidation. Thus, the material remaining in the ashes is mineral matter. This mineral mass is then determined by a weighing procedure in controlled conditions. This protocol insures a good repeatability and reliability ( $\pm 10-3 \mathrm{~g}$ by filter) in the determination of the mineral masses, limiting the loss of particles during filter handling (especially for filters highly loaded with dust particles). Moreover, if small insects, vegetal debris, pollens or other organic matters are collected on the filters, they are manually removed only if this manipulation does not affect the sample. If the removal of these elements could damage the sample, we leave them on the filter considering that samples ignition eliminates the organic matter (Laurent et al., 2015). 


\subsection{Air mass trajectories and satellite observations}

Air mass trajectories and satellite observations can be jointly analysed to point out the provenance of the dust deposition measured at the stations.

Air masses trajectories computed using the HYSPLIT model (Draxler and Rolph, 2003; https://ready.arl.noaa.gov/ HYSPLIT.php) are commonly used to trace the origin of the air masses transporting mineral dust (Escudero et al., 2011; Meloni et al., 2008) or atmospheric pollutants (Jorba et al., 2004; Pongkiatkul and Kim Oanh, 2007). The statistical analysis of numerous backward trajectories from receptor sites has turned out to be a valuable tool to identify sources of atmospheric trace substances (Stohl, 1998; Scheifinger and Kaiser, 2007).

Since the transport of Saharan air masses towards the western Mediterranean basin can occur at various altitudes in the troposphere (Bergametti et al., 1989; Martin et al., 1990; Hamonou et al., 1999; di Sarra et al., 2001; Israelevich et al., 2002; Meloni et al., 2008; di Iorio et al., 2009), 4-day backward air mass trajectories starting every day at 12:00 UTC were computed starting at $0,500,2000,3000,4000$ and $5000 \mathrm{~m}$ a.g.l. for each of the five sampling stations. When the circulation of the model air masses slows over the western Mediterranean basin, the duration of the backward trajectories was extended to 6 days.

These air mass trajectories were combined with aerosol optical depth (AOD) products of the Moderate Imaging Spectrometer (MODIS; http://modis.gsfc.nasa.gov/) to identify, as best as possible, the provenance of the Saharan dust plume. The daily MODIS deep blue AOD at $550 \mathrm{~nm}$ over land and MODIS AOD at $550 \mathrm{~nm}$ over the oceanic surfaces (Levy et al., 2013) were used. When MODIS AOD was unavailable due to cloud cover, we also examined the EUMETSAT Monitoring weather and climate from space, Meteosat Second Generation (MSG) Spinning Enhanced Visible and Infrared Imager (SEVIRI) dust false-colour composite product available from ICARE Geo Browse Interface (http://www.icare.univ-lille1.fr/), which gives the opportunity to follow the transport of the dust plume every $15 \mathrm{~min}$ (e.g. Schepanski et al., 2007).

Once the dust provenance is identified, the HYSPLIT model was also used to compute forward air mass trajectories in ensemble mode (i.e. multiple trajectories from the selected starting location by offsetting the meteorological data) or in matrix mode (i.e. starting from the borders of these identified dust sources). These forward air mass trajectories at 00:00 and 12:00 UTC were computed starting from the dust provenance area at an altitude of $500 \mathrm{~m}$ a.g.l., which can be considered as a common dust entrainment altitude (Meloni et al., 2008). We checked the coherence between the backward and forward air mass trajectories computed for studied dust cases. We also checked for each forward trajectory the altitude of the air mass and if precipitation occurred during transport.

\section{Results and discussion}

\subsection{Weekly mineral dust deposition in the western Mediterranean basin}

The weekly fluxes of insoluble mineral deposition measured at the five sites are reported in Fig. 3. The highest weekly deposition fluxes are recorded at the two stations nearest to the Sahara desert: 3.2 and $2.7 \mathrm{~g} \mathrm{~m}^{-2} \mathrm{wk}^{-1}$ were measured respectively at Majorca and Lampedusa. The maximum deposition recorded for the stations located in the north-western Mediterranean basin and southern France (Corsica, Frioul and Le Casset) is almost 1 order of magnitude lower (0.53, 0.34 and $0.17 \mathrm{~g} \mathrm{~m}^{-2} \mathrm{wk}^{-1}$, respectively). The same trend is observed when considering the deposition fluxes cumulated over a 1-year period without sampling discontinuities. In fact, the highest annual deposition fluxes are $7.4 \mathrm{~g} \mathrm{~m}^{-2}$ year $^{-1}$ in Lampedusa for 2012, $5.8 \mathrm{~g} \mathrm{~m}^{-2}$ year $^{-1}$ in Majorca for 2013, $2.1 \mathrm{~g} \mathrm{~m}^{-2}$ year $^{-1}$ in Corsica for 2013, $3.5 \mathrm{~g} \mathrm{~m}^{-2}$ year $^{-1}$ in Frioul for 2012 and $0.9 \mathrm{~g} \mathrm{~m}^{-2}$ year $^{-1}$ in Le Casset for 2012. Thus, a south-north decreasing gradient in the intensity of the mineral dust deposition is observed over the western Mediterranean basin with a flux about 2 to 8 times lower in the northern part of the basin and southern France than in the southern basin. Previous observations also pointed out a gradient of dust content in the western Mediterranean atmosphere (see for example Barnaba and Gobbi, 2004; Pey et al., 2013).

In the late 1980s and 2000s, the mean annual Saharan dust deposition measured in Corsica by Loÿe-Pilot et al. (1986), Loÿe-Pilot and Martin (1996) and Ternon et al. (2010) were of 14.0, 12.5 and $11.4 \mathrm{~g} \mathrm{~m}^{-2}$ year ${ }^{-1}$, respectively. Bergametti et al. (1989) also measured a mean annual deposition of $11.0 \mathrm{~g} \mathrm{~m}^{-2}$ year $^{-1}$ in Corsica. These deposition fluxes are significantly higher than the one we measured at the Corsica station from January to December 2013. These studies also point out a high inter-annual variability of the atmospheric deposition in the western Mediterranean basin. Investigating 11 years of atmospheric deposition in Corsica, Loÿe-Pilot and Martin (1996) reported deposition fluxes ranging from 4 to $26.2 \mathrm{~g} \mathrm{~m}^{-2}$ year $^{-1}$. These authors indicate that no deposition event greater than $1 \mathrm{~g} \mathrm{~m}^{-2}$ was recorded in the years for which the annual atmospheric deposition was low in Corsica, suggesting that the interannual variability of dust deposition in Corsica was driven by the annual occurrence of very intense Saharan dust deposition events. The contribution of such dust pulses to the annual atmospheric deposition flux in the western Mediterranean has been mentioned many times in the literature. For example, Bergametti et al. (1989) reported that a deposition event of only 3 days occurring in March 1986 has contributed to more than $30 \%$ of the annual atmospheric deposition measured in Corsica for elements such as Al or Si. Guerzoni et al. (1997) also mentioned that a single Saharan dust outbreak can account for 40-80\% of the annual deposition flux. In February 2004, Ternon et 


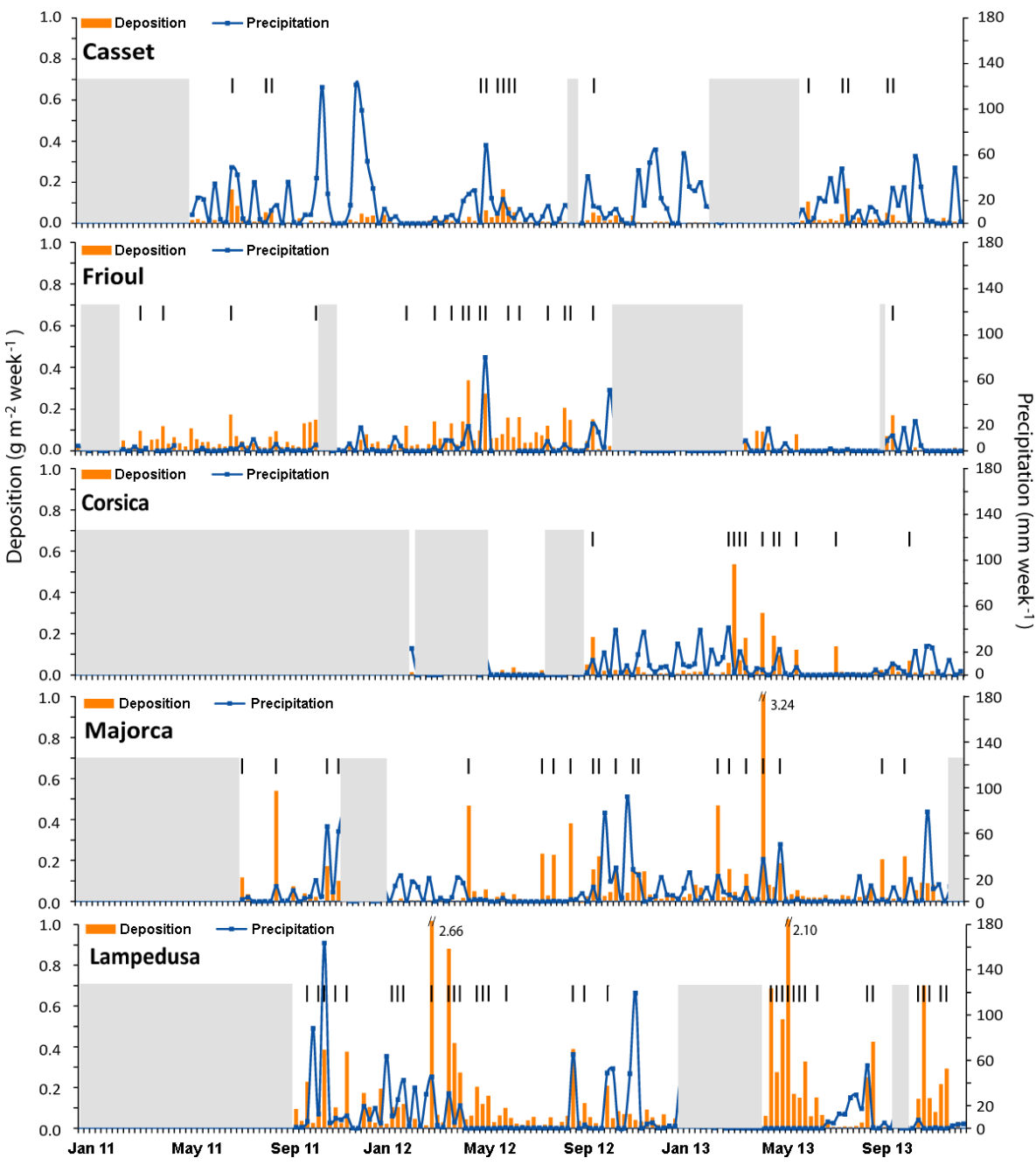

Figure 3. Weekly insoluble mineral deposition fluxes (orange bars) and precipitation amount (blue line) for Lampedusa, Majorca, Corsica, Frioul and Le Casset from January 2011 to December 2013. The grey areas correspond to periods without sampling. The numbers of most intense dust deposition for each station as described in Sect. 4.3 are indicated by black bars above the deposition flux values: 34 in Lampedusa, 20 in Majorca, 11 in Corsica, 18 in Frioul and 15 in Le Casset.

al. (2010) measured an extreme case of dust deposition in the Ligurian sea area $\left(22 \mathrm{~g} \mathrm{~m}^{-2}\right.$ for 2 weeks). This Saharan dust event represented almost $90 \%$ of the Saharan inputs reported for 2004 at the Cap Ferrat site (Ternon et al., 2010).

The annual deposition flux we measured in Corsica corresponds to a low dust deposition year. This is also supported by the fact that none of the weekly deposition fluxes we measured exceeds $1 \mathrm{~g} \mathrm{~m}^{-2}$, the higher deposition flux measured in Corsica being $0.53 \mathrm{~g} \mathrm{~m}^{-2} \mathrm{wk}^{-1}$. However, compared to previous deposition measured in Corsica, even the annual deposition fluxes measured at the southern stations of the western Mediterranean basin (Lampedusa and Majorca) are lower, suggesting that the years 2011, 2012 and 2013 probably correspond to a low atmospheric deposition period. This observation is in agreement with the analysis performed by Pey et al. (2013) from $\mathrm{PM}_{10}$ measurements performed in the Mediterranean region over the period 2001-2011 which concluded to a decrease of the contribution of Saharan dust events to the $\mathrm{PM}_{10}$ load. As mentioned by these authors and according to the study of Moulin et al. (1997), this decrease in the Saharan dust transport over the western Mediterranean Sea is probably due to the continuous decrease of the North Atlantic Oscillation (NAO) index in winter during the period 1990-2012 and in summer since 2006.

\subsection{Selection of the most intense weekly deposition fluxes}

The previous studies mentioned above indicated that the largest deposition events observed in the western Mediterranean basin are strongly associated with Saharan dust transports (Bergametti et al., 1989; Loÿe-Pilot and Martin, 1996; Guerzoni et al., 1999). We decided to give particular at- 


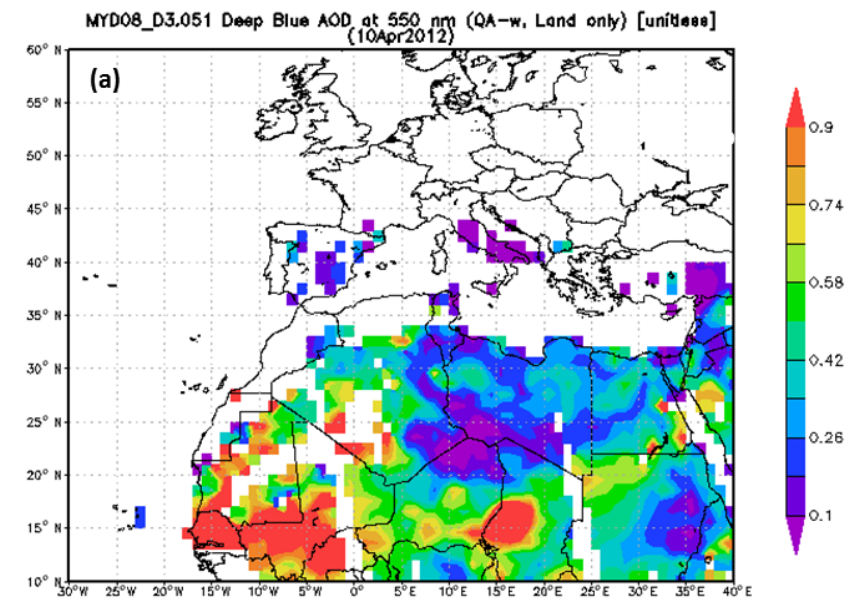

NOAA HYSPLIT MODEL

Backward trajectories ending at 1200 UTC 13 Apr 12 GDAS Meteorological Data

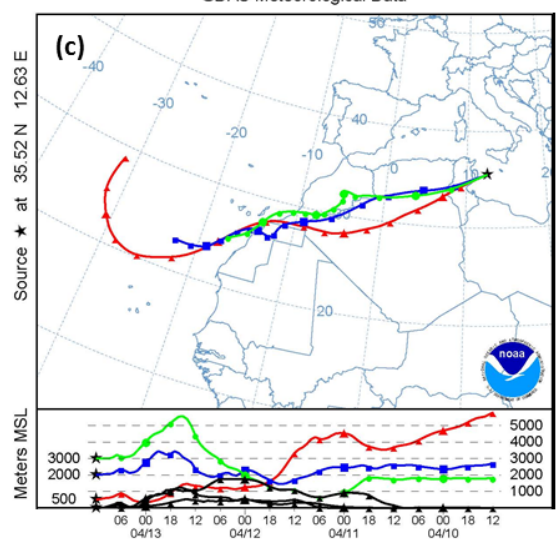

NOAA HYSPLIT MODEL Forward trajectories starting at 0000 UTC 10 Apr 12 GDAS Meteorological Data

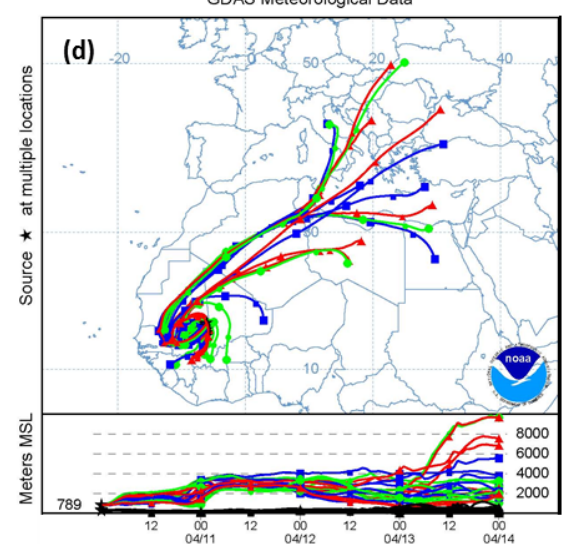

MSG/SEVIRI «DUST »

10 Apr. $201212 \mathrm{~h}$

Icare Univ. Lille1

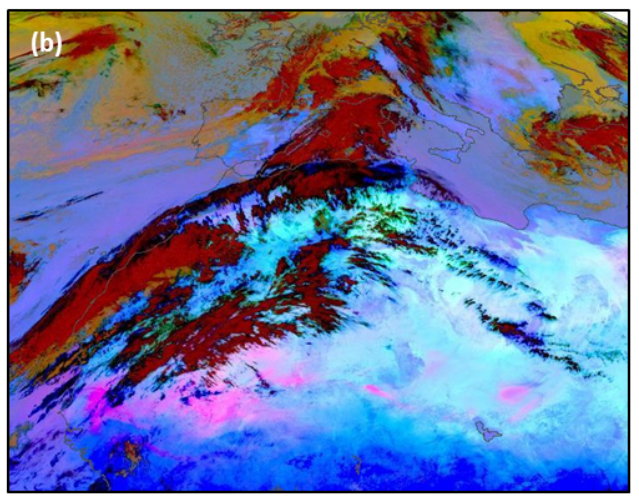

NOAA HYSPLIT MODEL

Forward trajectories starting at 0000 UTC $10 \mathrm{Apr} 12$

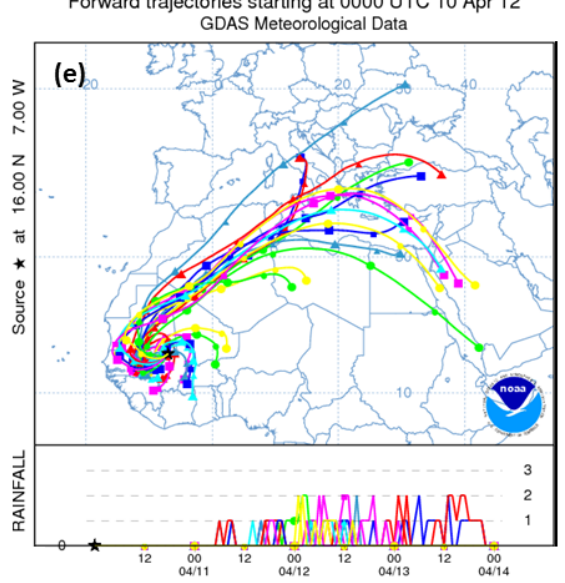

Figure 4. Illustration of the data used jointly to identify a dust transport event and its origin, which leads to high deposition in Lampedusa between April 12 and 13 2012. (a) MODIS deep blue AOD, (b) MSG/SEVIRI dust false-colour composite product, (c) HYSPLIT backward trajectories for three starting heights $(500,2000$ and $3000 \mathrm{~m})$, (d) HYSPLIT forward trajectories in matrix mode with corresponding altitudes, (e) HYSPLIT forward trajectories in ensemble mode with corresponding precipitation.

tention to the most intense weekly deposition (MID) flux measured at each station and to verify if these high deposition events were linked to Saharan dust transport towards the Mediterranean Sea. We cannot exclude that local mineral contribution, especially during high wind speed periods at the station, may affect some samples, in particular those for which the deposition due to long-range transported dust is the lowest. Moreover, for the station located the furthest from the African coasts, such as Frioul or Le Casset, the anthropogenic background in refractive material may also contribute in a limited way to the insoluble mineral deposition. Among the MID, the most intense Saharan dust deposition (MIDD) samples and the corresponding dust deposition events (DDE) will be discussed.

To select the MID, we first merged all the weekly samples collected at the different stations (537 samples) and then selected the weekly deposition greater than the last sextile of the data set, i.e. the $16.67 \%$ highest deposition values (i.e.
90 samples). This leads to a threshold weekly deposition flux of $9.3 \times 10^{-2} \mathrm{~g} \mathrm{~m}^{-2} \mathrm{wk}^{-1}$. The 90 highest deposition values were thus retained by using this threshold, independent of the station where they have been measured. However, as shown before, the intensity of the atmospheric deposition is higher at the stations located nearest to the North African dust source areas. This means that even a relatively high deposition event occurring in the northern part of the basin may be excluded from the selection because its deposition flux is lower than the overall threshold value. To correct this bias, we added a second criterion, which also consists in retaining, for a given station, all the samples for which the weekly deposition flux is greater than the geometric mean $\left(m_{\mathrm{g}}\right)$ plus the geometric standard deviation $\left(\sigma_{\mathrm{g}}\right)$ calculated for each station, i.e. $m_{\mathrm{g}} \cdot \sigma_{\mathrm{g}}$, statistical tests having shown that the deposition fluxes measured at each station fitted either a lognormal or a Gamma distribution (values below $10^{-4} \mathrm{~g}$ for a sample were assumed to be equal to this weighing detection 
Table 2. Number of weekly deposition fluxes measured, number (and relative proportion in \%) of the most intense weekly deposition fluxes recorded (MID), number of MID events with identified Saharan provenance area (MIDD), and their respective contribution (\% in mass) to the deposition fluxes measured, at each station of the network.

\begin{tabular}{lrrrrrr}
\hline & $\begin{array}{r}\text { Number of } \\
\text { weekly } \\
\text { samples }\end{array}$ & $\begin{array}{r}\text { Total } \\
\text { deposition }\end{array}$ & $\begin{array}{r}\text { Threshold } \\
\text { flux } \\
\left(\mathrm{g} \mathrm{m}^{-2} \text { year }^{-1}\right)\end{array}$ & $\begin{array}{r}\text { MID } \\
\left(\mathrm{g} \mathrm{m}^{-2} \mathrm{wk}^{-1}\right)\end{array}$ & $\begin{array}{r}\text { MID contribution } \\
\text { to total deposition } \\
\text { fluxes (\%) }\end{array}$ & $\begin{array}{r}\text { MIDD } \\
\text { MIDD } \\
\text { contribution to } \\
\text { total deposition } \\
\text { fluxes }(\%)\end{array}$ \\
\hline Le Casset & 119 & 2.17 & 0.036 & $18(15 \%)$ & 61 & 15 \\
Frioul & 123 & 5.84 & 0.093 & $21(17 \%)$ & 55 & 18 \\
Corsica & 78 & 2.59 & 0.050 & $11(14 \%)$ & 73 & 11 \\
Majorca & 117 & 9.74 & 0.093 & $21(18 \%)$ & 80 & 20 \\
Lampedusa & 100 & 16.0 & 0.093 & $37(37 \%)$ & 87 & 34 \\
\hline
\end{tabular}

limit). This second criteria allows for the minimum selection of the upper sextile of a lognormal distribution. It leads to the selection of 18 additional samples at the two stations where the average fluxes are the lowest: 4 more samples from Corsica (fluxes $>0.050 \mathrm{~g} \mathrm{~m}^{-2} \mathrm{wk}^{-1}$ ) and 14 from Le Casset $\left(>0.036 \mathrm{~g} \mathrm{~m}^{-2} \mathrm{wk}^{-1}\right)$. Table 2 reports the 108 MID distribution by station, $54 \%$ of them having been sampled in the southern stations of Lampedusa and Majorca. The MID represent at least more than half of the whole deposition flux measured at each station (Table 2).

The MID events being selected, we verified whether these deposition events were associated or not with air masses originating from the Saharan desert. To point out the provenances and the main transport pathways of deposition events at each station, HYSPLIT air mass trajectories and satellite aerosol observations were jointly analysed as presented in Sect. 3.4. Among the 108 MID samples, only one sample collected at Le Casset was not associated with at least one air mass trajectory having crossed northern Africa during the sampling week.

For each MID, we identified by using MODIS AOD or MSG satellite observations where dust is coming from. Figure 4 illustrates the different satellite observations and air mass trajectories used to identify the dust provenance area and transport pattern associated with dust deposition in the western Mediterranean basin. In all, 98 samples among the 107 MID present an air mass coming from North African areas with high AOD and reaching the stations. Hereafter, these 98 most intense Saharan dust deposition samples are called MIDD. For the remaining nine cases, the absence of matching between high AOD observed from satellite images and air mass trajectories linking the dust provenance region to the sampling stations does not necessary mean that these cases are not cases of Saharan dust deposition. The MIDD accounts for 84, 78 and $73 \%$ of the deposition in Lampedusa, Majorca and Corsica, respectively, while it contributes around $50 \%$ in Frioul and Le Casset (Table 2).

\subsection{Seasonality of the most intense dust deposition (MIDD)}

To look at the seasonality of the MIDD occurrence for the studied period, the fact that each month of the year has not been sampled with the same frequency at each sampling station has to be taken into account. We computed the number of weeks which have been sampled for each month and for each station. A weighting coefficient $a_{(M)}$ was computed for each station by dividing the number of sampled weeks for each month $(M)$ by the total number of weeks of sampling at each station. $F_{(M)}$, the weighted number of MIDD occurrences for a given per month $M$, was then computed as

$F_{(M)}=\frac{N_{(M)}}{a_{(M)}}$,

where $N_{(M)}$ is the number of MIDD during a given month.

Figure 5 reports the number of MIDD occurrence per month at each site. Most of the MIDD occurred during spring (March-June): $53 \%$ in Le Casset, $49 \%$ in Frioul, $81 \%$ in Corsica, $38 \%$ in Majorca and $55 \%$ in Lampedusa. A second maximum is observed in autumn in Majorca and Lampedusa, and at the end of summer and early autumn in Frioul, Corsica and Le Casset. From their long-term data set in Corsica, Loÿe-Pilot and Martin (1996) also observed the most frequent and intense dust events in spring and autumn. According to Bergametti et al. (1989), the frequency of Saharan inputs in Corsica seems to be the highest during spring and summer, $80 \%$ of the events being observed between March and October 1985. Ternon et al. (2010) observed high deposition in spring and summer with a maximum in June from their measurements performed in the Ligurian area between 2003 and 2007. Avila et al. (1997) showed that the occurrence of red rain episodes in north-eastern Spain between 1983 and 1994 were higher in autumn and spring. The dust deposition seasonality cannot be directly compared with other atmospheric observations. For instance in Lampedusa, the seasonality of atmospheric dust content and dust deposition are different. Maximum AOD indicate the highest dust atmospheric content in summer in 2001-2005 (Meloni et 


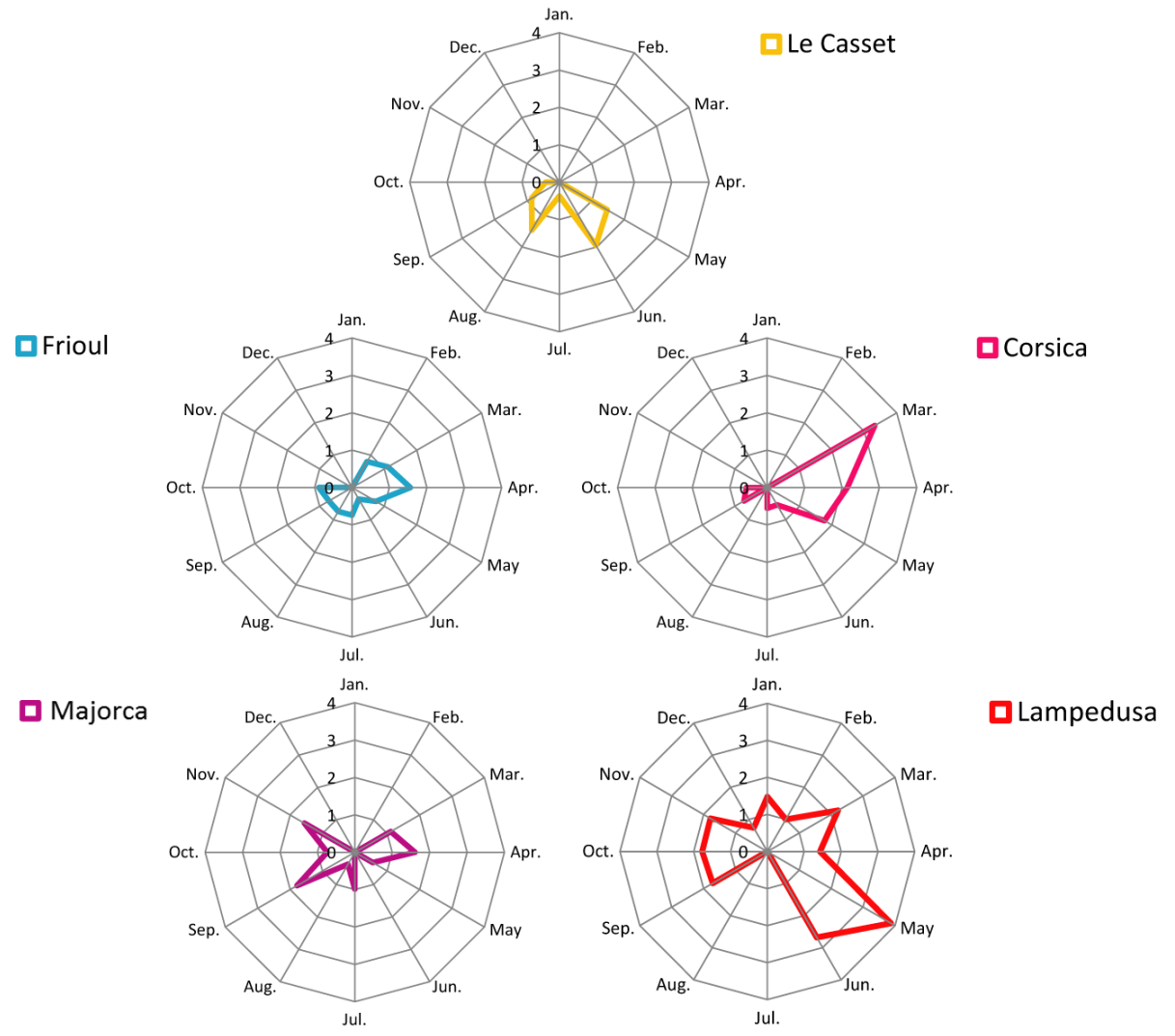

Figure 5. Weighted number of occurrence of MIDD per month over the whole sampling period at each site.

al., 2004, 2008), whereas the crustal aerosol contribution to $\mathrm{PM}_{10}$ measurements performed between 2004 and 2010 does not show any evident seasonal pattern. Marconi et al. (2014) mentioned that in Lampedusa no significant correlation between aerosol optical thickness and $\mathrm{PM}_{10}$ or non-sea-salt $\mathrm{Ca}$ is found for the period June 2004-December 2010. These authors suggested that even when the dust is very likely present in the lower and mid-troposphere simultaneously, the aerosols observations at the surface are generally decoupled from what takes place above in the atmospheric column.

Our results point out that the stations of the network are not systematically concerned by dust deposition at the same period. To fully understand the variability of Saharan dust deposition in the western Mediterranean basin, several sampling sites are required to perform direct deposition measurements.

\subsection{Identification of Saharan dust deposition events}

The number of stations operating when a MIDD was recorded is given in Table 3. In all, 98 MIDD have been collected during 75 different weeks of sampling and $82 \%$ of these MIDD were recorded when at least four stations were simultaneously operating. However, only 17 of these MIDD have affected more than one station during the same sampling week (12 at two stations, 4 at three stations, and
1 at four stations). Furthermore, $75 \%$ of the cases were affected when at least two stations recorded a MIDD associated the Majorca stations or the Lampedusa station with northern stations, whereas only two cases associated at least both Lampedusa and Majorca stations. The stations the most often associated with a given MIDD are (i) Frioul and le Casset (six cases for which at least these two stations are associated), (ii) Majorca and Corsica (five cases for which at least these two stations are associated). This suggests that, in the western Mediterranean basin, the MIDD are associated with different dust provenance and transport pathways, and/or the dust plumes are washed out by precipitation during their transport over the basin.

The joint analysis of the HYSPLIT air mass trajectories and MODIS AOD allows us to identify where dust deposited at the stations for the MIDD is likely coming from. During a sampling week, several DDE can be identified and contribute to the weekly deposition flux. A dust event contributing to dust deposition during several days at a station is considered as a single DDE. A MIDD can be a combination of several DDE originating from different dust areas. We identified 132 DDE for the studied period: 50 reached Lampedusa, $27 \mathrm{Ma}-$ jorca, 22 Frioul, 15 Corsica and 18 Le Casset. The number of events contributing to the dust deposition is greater for the stations close to the North African dust sources. 


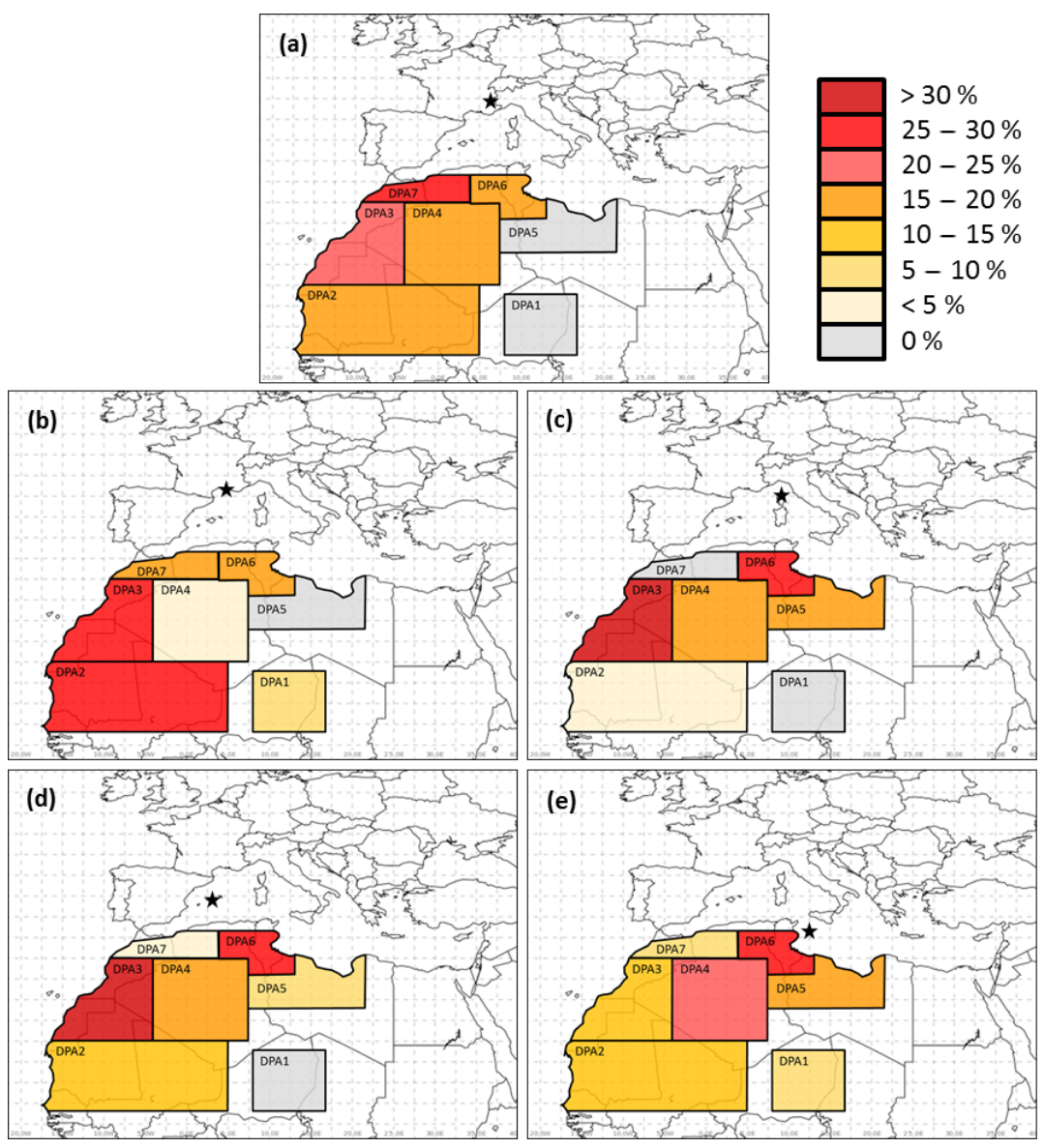

Figure 6. Frequency of dust provenance areas identified using MODIS AOD and HYSPLIT air mass trajectories for the DDE contributing to the MIDD recorded at (a) Le Casset, (b) Frioul, (c) Corsica, (d) Majorca and (e) Lampedusa.

Table 3. Number of stations operating and number of stations recording a MIDD during the same sampling week.

\begin{tabular}{lrrrrrrrr}
\hline & \multicolumn{8}{c}{$\begin{array}{c}\text { Number of stations recording } \\
\text { simultaneously a MIDD }\end{array}$} \\
\cline { 2 - 8 } & 5 & 4 & 3 & 2 & 1 & Total \\
\hline Number of & 5 & 0 & 1 & 0 & 3 & 23 & 27 \\
stations operating & 4 & - & 0 & 4 & 7 & 23 & 35 \\
& 3 & - & - & 0 & 0 & 7 & 4 \\
& 2 & - & - & - & 2 & 2 & 6 \\
& 1 & - & - & - & - & 3 & 3 \\
\hline & Total & 0 & 1 & 4 & 12 & 58 & 75 \\
\hline
\end{tabular}

For each DDE, the localisation of the highest AOD southernmost along the modelled air mass trajectory defined a rough region where dust comes from. As mentioned by Meloni et al. (2008), due to the low resolution of the model meteorological fields and transport model intrinsic errors, the dust location can be relatively wide. It should also be kept in mind that other sources located along the pathway of the dust plume can also contributed to the dust uplifts. Thus, we defined seven large dust provenance areas (DPA) by grouping together the closest dust localisations (Fig. 6): Niger and Chad (DPA1), northern Mali and southern Mauritania (DPA2), Western Sahara and southern Morocco (DPA3), central Algeria (DPA4), Libya (DPA5), Tunisia and eastern Algeria (DPA6), and northern Morocco and north-western Algeria (DPA7).

The number of DDE at each station (weighted as in Sect. 3.3 and expressed in \%) originating from the seven areas are reported in Fig. 6; $73 \%$ of DDE in Frioul and $69 \%$ of DDE in Le Casset come from the western part of the Sahara (DPA2, 3 and 7). Western Sahara (DPA3) and Tunisia (DPA6) are the most frequent provenance of DDE reaching Majorca. Dust deposited during the DDE in Lampedusa generally come from the Tunisian (DPA6) and Libyan (DPA5) regions and central Algeria (DPA4). DDE in Corsica generally come from the Western Sahara and southern Morocco (DPA3), Tunisia and eastern Algeria (DPA6) and Libya (DPA5), and the same level of similarity can be observed between the dust provenance areas affecting Majorca and Corsica than between Corsica and Lampedusa. We also 

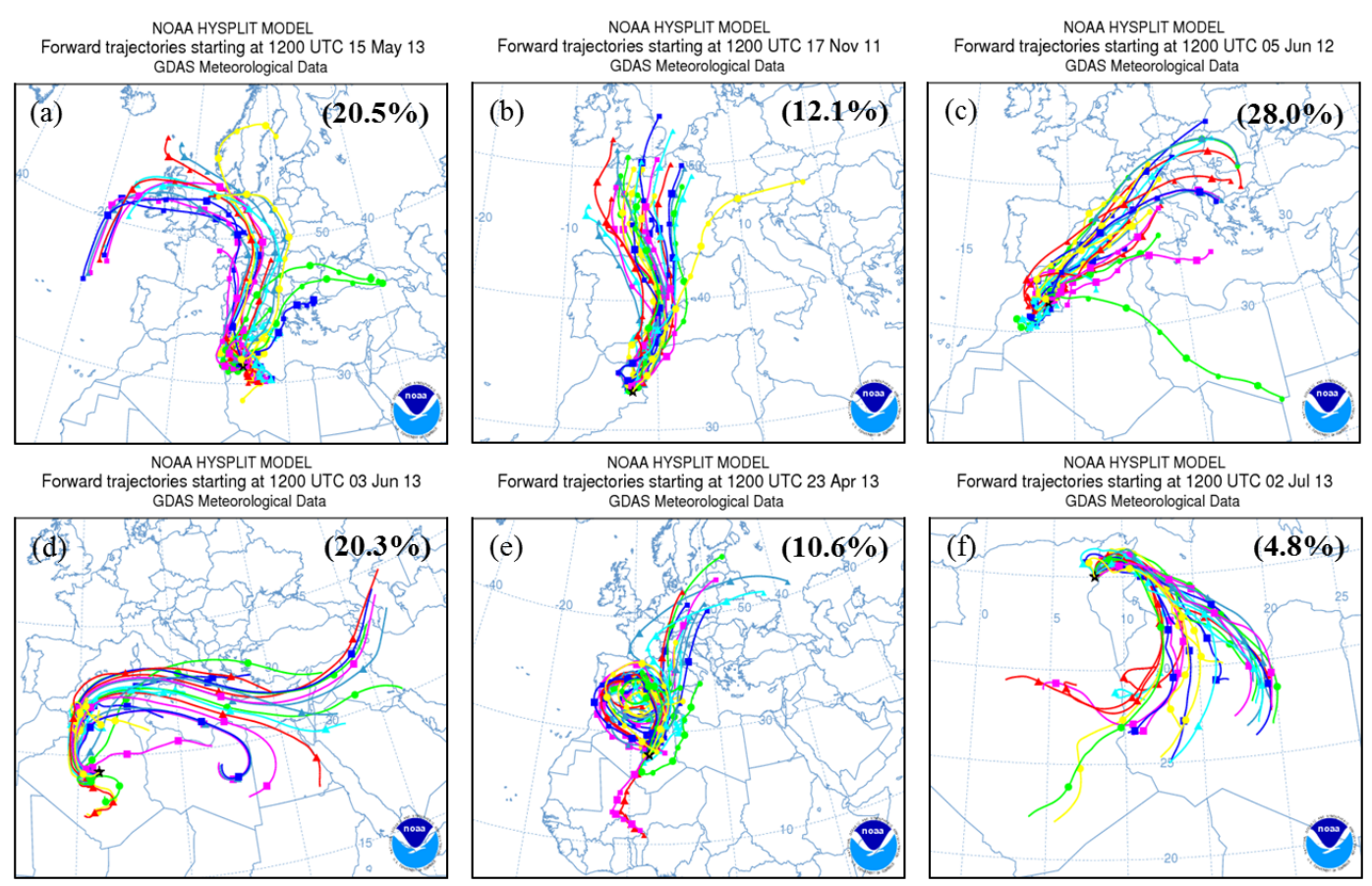

Figure 7. Typical forward air mass trajectories computed with the HYSPLIT model and corresponding to the different Saharan deposition events collected over the western Mediterranean basin. The number in brackets indicates the relative occurrence frequency for each of the six cases $(3.7 \%$ are unclassified).

noted that provenance areas, even south of $20^{\circ} \mathrm{N}$, like Niger and Chad (DPA1), and northern Mali and southern Mauritania (DPA2), could contribute to DDE (DPA1 for Frioul and Lampedusa, DPA2 for all the stations). Tunisian and Libyan sources have been pointed out by Salvador et al. (2014) for specific dust outbreak observed in spring in Balearic islands and central Mediterranean. This dust transport pathway can be due to high pressure systems located over these sources (Salvador et al., 2014). Moreover, Marconi et al. (2014) also pointed out source regions located in Tunisia-Algeria and Libya to explain atmospheric dust content in Lampedusa. Meloni et al. (2008) indicated the Morocco, Algeria and Tunisia as dust loading areas, as well as southern areas in Mauritania-Mali.

These results confirm that the different parts of the western Mediterranean basin are not affected in the same proportion by Saharan dust coming from different regions. It is nevertheless important to keep in mind that what was tracked here is the southernmost occurrence of dust along the trajectory associated with intense dust deposition events. Hamonou et al. (1999) showed that dust layers of different origins can also be present concurrently over a given station in the northern part of the Mediterranean.

\subsection{Transport routes of the Saharan dust deposition events}

The main transport routes associated with the 132 DDE in the western Mediterranean Sea were investigated. We classified the forward air mass trajectories computed for each DDE depending on their pathway. The six most frequent types of trajectories (representing $96.3 \%$ of all trajectories) are illustrated in Fig. 7. Note that four cases among them were classified as "others", each of them corresponding to a trajectory observed only one time during the studied period. The air mass trajectories over the western Mediterranean basin are often transported in high altitude (Escudero et al., 2005; Querol et al., 2009). Low level transport of dust are mostly observed at Lampedusa. Trajectory types (a), (c) and (d) are the most frequent transport ways of Saharan dust towards the western Mediterranean basin, since they all together account for almost $70 \%$ of all trajectories. Trajectory type (a) corresponds to a straight transport of dust emitted from sources located in Tunisia and/or Libya towards Lampedusa and the eastern part of western Mediterranean basin. This type of trajectory is the dominant transport in spring (Fig. 8). Trajectory type (c) corresponds to transport from sources located in western Algeria/Morocco and Mauritania/Mali towards the western part of the basin and type (d) to transport in a west to east flow from sources located in western and central Sahara and mainly towards the south-western Mediterranean Basin. They are the dominant Saharan dust transport 


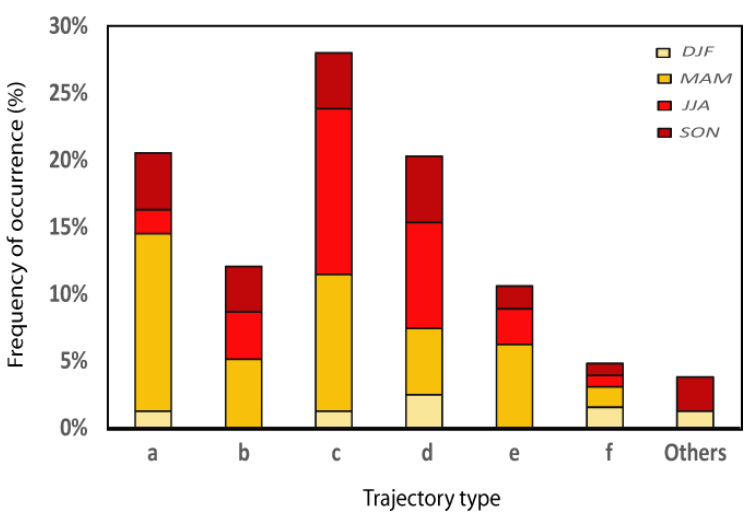

Figure 8. Seasonal occurrence of the different Saharan dust trajectories (see text for details).

pathways during summer (Fig. 8). These trajectories have already been mentioned in previous studies as major transport ways for Saharan dust over the Mediterranean Sea (Bergametti et al., 1989; Guerzoni et al., 1997; Moulin et al., 1998; Israelevich, 2003; Meloni et al., 2008; Marconi et al., 2014). Even if they are less frequent, Saharan dust transport trajectories of type (b) (straight transport towards the westernmost part of the Mediterranean basin from sources located in northern Morocco and western Algeria) and (e) (stagnant air masses and cyclonic flow centred over the Atlas and southern Mediterranean) represent 12.1 and $10.6 \%$ of all trajectories, and often occur in spring (Fig. 8).

HYSPLIT model trajectories and precipitation were used to examine whether the different transport trajectories to the western Mediterranean Basin were systematically associated or not with precipitation during transport. We consider a trajectory with an occurrence of precipitation along its path between the Saharan dust provenance area and a given station as a "wet transport case", whatever the rainfall rate. Main uncertainties are due to the low spatial resolution of the meteorological data set, which prevents, for example, accounting for the summer precipitation due to convective cells (Meloni et al., 2008). Moreover, the precipitation is precipitation rate at the grid cell where the trajectory is located and does not take into account the air mass altitude transport. Figure 9 presents the proportion of Saharan dust trajectories coming from each dust provenance area (identified in Sect. 3.4) and for which precipitation during transport have been computed by the HYSPLIT model. Dust air masses from the Western Sahara have the highest probability $(>60 \%)$ to be washed during transport. On the opposite, dust air masses from southern and central Sahara are transported about 2/3 of the time in dry conditions. This suggests a more efficient transport of dust from these Saharan regions to the western Mediterranean basin. Air masses coming from the most eastern source regions exhibit intermediate values, with a $50 \%$ probability to be washed during transport.

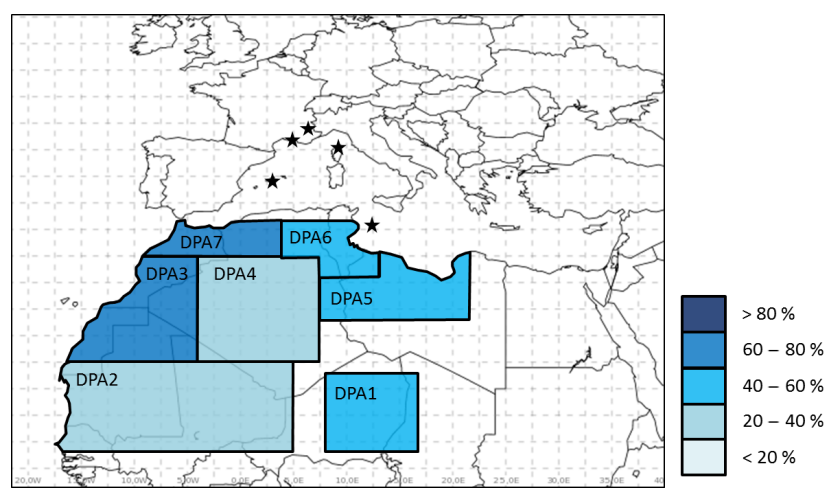

Figure 9. Proportion of HYSLPIT trajectories for the DDE (in \%) with precipitation during their transport between the source regions and the western Mediterranean basin.

Results on dust provenance and transport pathways of the DDE suggest that different parts of the western Mediterranean basin are affected by dust deposition events at different periods and from different dust source regions. Dust masses follow different transport trajectories to reach the Mediterranean, some of them being probably washed by precipitation during their transport. This means that Saharan dust inputs to the different parts of the western Mediterranean Basin do not occur at the same time, and can differ in intensity and in composition.

\subsection{Dry and wet deposition}

In this study, no direct measurements of dry-only and wetonly deposition are performed. However, in order to provide information on the relative importance of dry and wet deposition to the MIDD, the daily precipitation measured were analysed in combination with forward dust air mass trajectories starting from the identified provenance areas and reaching the sampling sites. When no precipitation is recorded, we consider that dust deposition is driven by dry deposition processes. As mentioned by Löye-Pilot and Martin (1996), significant deposits can occur in almost "dry conditions", i.e. very low and short rain events and/or fog periods that classical meteorological rain gauges cannot detect. As a consequence, in these cases, the deposition is considered as dry and this leads to a possible overestimation of the contribution of the dry-only deposition to the total deposited flux. The air mass trajectories provide for each identified dust event a theoretical date of its arrival at a given sampling station. As mentioned above, there are uncertainties on the computed trajectories due to both the model and the resolution of the meteorological fields. Moreover, in most cases, the starting date of the trajectory from the source regions (as determined by looking at the satellite images) is known with a precision not better than $\pm 12 \mathrm{~h}$. Thus, a dust deposition event for which no precipitation is recorded at the station $24 \mathrm{~h}$ before and up to $72 \mathrm{~h}$ after the dust plume arrival is defined as "dry". 
Table 4. MIDD during which DDE occur only by dry, by wet or by mixed (wet + dry) deposition. The wet (or dry) conditions are defined considering the precipitation occurrence (or not) during the $24 \mathrm{~h}$ before the arrival time of a dust plume at the sampling sites according to the air mass trajectories and 24, 48 and $72 \mathrm{~h}$ after its arrival time. * Precipitation data were not available for one MIDD at the Frioul station.

\begin{tabular}{|c|c|c|c|c|c|c|c|c|c|}
\hline & \multirow[b]{2}{*}{$\begin{array}{r}\text { Time } \\
\text { period } \\
\text { after dust } \\
\text { arrival }\end{array}$} & \multicolumn{4}{|c|}{ Number of MIDD } & \multicolumn{4}{|c|}{ MIDD cumulated mass } \\
\hline & & Total & $\begin{array}{r}\text { Wet } \\
\text { deposition }\end{array}$ & $\begin{array}{r}\text { Dry } \\
\text { deposition }\end{array}$ & $\begin{array}{r}\text { Wet }+ \text { dry } \\
\text { deposition } \\
\text { (mixed) }\end{array}$ & $\begin{array}{l}\text { Total mass } \\
\quad\left(\mathrm{g} \mathrm{m}^{-2}\right)\end{array}$ & $\begin{array}{r}\text { Wet } \\
\text { deposition } \\
(\%)\end{array}$ & $\begin{array}{r}\text { Dry } \\
\text { deposition } \\
(\%)\end{array}$ & $\begin{array}{l}\text { Wet + dry } \\
\text { deposition } \\
\text { (mixed, \%) }\end{array}$ \\
\hline \multirow[t]{3}{*}{ Le Casset } & $24 \mathrm{~h}$ & 15 & 12 & 3 & - & 1.2 & 77 & 23 & - \\
\hline & $48 \mathrm{~h}$ & & 13 & 1 & 1 & & 82 & 14 & 4 \\
\hline & $72 \mathrm{~h}$ & & 13 & 1 & 1 & & 82 & 14 & 4 \\
\hline \multirow[t]{3}{*}{ Frioul } & $24 \mathrm{~h}$ & $17^{*}$ & 10 & 6 & 1 & 2.7 & 61 & 27 & 12 \\
\hline & $48 \mathrm{~h}$ & & 11 & 5 & 1 & & 66 & 22 & 12 \\
\hline & $72 \mathrm{~h}$ & & 11 & 5 & 1 & & 66 & 22 & 12 \\
\hline \multirow[t]{3}{*}{ Corsica } & $24 \mathrm{~h}$ & 11 & 7 & 3 & 1 & 1.9 & 69 & 15 & 16 \\
\hline & $48 \mathrm{~h}$ & & 7 & 3 & 1 & & 69 & 15 & 16 \\
\hline & $72 \mathrm{~h}$ & & 8 & 2 & 1 & & 74 & 10 & 16 \\
\hline \multirow[t]{3}{*}{ Majorca } & $24 \mathrm{~h}$ & 20 & 12 & 6 & 2 & 7.6 & 36 & 15 & 49 \\
\hline & $48 \mathrm{~h}$ & & 14 & 4 & 2 & & 41 & 10 & 49 \\
\hline & $72 \mathrm{~h}$ & & 14 & 4 & 2 & & 41 & 10 & 49 \\
\hline \multirow[t]{3}{*}{ Lampedusa } & $24 \mathrm{~h}$ & 34 & 18 & 15 & 1 & 13.5 & 51 & 46 & 3 \\
\hline & $48 \mathrm{~h}$ & & 18 & 15 & 1 & & 51 & 46 & 3 \\
\hline & $72 \mathrm{~h}$ & & 18 & 15 & 1 & & 51 & 46 & 3 \\
\hline
\end{tabular}

The $72 \mathrm{~h}$ time period after the arrival of the dust air mass over the sampling site is split in three periods $(24,48$ and $72 \mathrm{~h}$ ) in order to take into account for the duration of the dust events that can last more than 1 day (Table 4). For each of the 98 MIDD, the numbers of dry, wet and mixed (wet + dry) DDE were computed. Obviously, this procedure underestimates the number of dry only deposition cases and provides only a lower estimate of dust dry DDE events relatively to the total DDE identified at each station.

Table 4 reports, for each sampling station, estimated proportions of the wet-only, dry-only and mixed DDE to MIDD (in terms of occurrences and mass fluxes). Between 36 and $82 \%$ of MIDD (depending on the sampling stations) occur in only wet conditions. The deposition in the northern stations is dominated by wet deposition ( 77 to $82 \%$ of the total mass deposition in Le Casset, 61 to $66 \%$ in Frioul, 69 to $74 \%$ in Corsica). For the southern stations, Lampedusa and Majorca, wet deposition could contribute to 51 and 36 to $41 \%$ of total deposition mass, respectively. Even if the wet or dry deposition events can be roughly classified following our approach, the occurrence and the intensity of dry deposition events are far to be negligible. In terms of mass, dry deposition represents between 10 and $46 \%$ of the deposited mass, the lower contribution being observed in the remote island sites of Majorca (10 to $15 \%)$ and Corsica (10 to $15 \%)$. The highest MIDD measured in Lampedusa $\left(2.7 \mathrm{~g} \mathrm{~m}^{-2} \mathrm{wk}^{-1} ; 20 \%\right.$ of the total deposition flux, respectively) corresponds to a single wet de- position DDE. However, the second highest MIDD measured in Lampedusa $\left(2.1 \mathrm{~g} \mathrm{~m}^{-2} \mathrm{wk}^{-1} ; 16 \%\right.$ of the total deposition flux) corresponds to two successive dry DDE. In this latter case, dust plumes were transported below $2000 \mathrm{~m}$. Such a low altitude dust transport in this area was also reported by Barnaba and Gobbi (2004). The highest MIDD measured in Majorca at the end of April 2013 (3.2 $\mathrm{g} \mathrm{m}^{-2} \mathrm{wk}^{-1} ; 42 \%$ of the total deposition flux) resulted from three DDE (one dry and two wet). For the studied period, our results shows that the most intense dust deposition fluxes can be due to single or several successive DDE and can involve wet deposition as well as dry deposition events.

\section{Conclusion}

A network of five sampling sites was deployed from 2011 on the western Mediterranean region to measure the insoluble atmospheric deposition fluxes. It included from south to north an Italian site (Lampedusa), a Spanish site (Majorca) and three French sites (Corsica, Frioul, and Le Casset in south-eastern France). The data recovery rate varied between 77 and $91 \%$ depending on the station. The deposition data set acquired between 2011 and 2013 include 537 weekly samples. It allowed us to investigate Saharan dust deposition events in this region.

At the three northern stations of the network, Le Casset $\left(44^{\circ} 59^{\prime} \mathrm{N}, 6^{\circ} 28^{\prime} \mathrm{E}\right)$, Frioul $\left(43^{\circ} 15^{\prime} \mathrm{N}, 5^{\circ} 17^{\prime} \mathrm{E}\right)$ and Corsica 
$\left(43^{\circ} 00^{\prime} \mathrm{N}, 9^{\circ} 21^{\prime} \mathrm{E}\right)$, the maximum deposition fluxes measured on a weekly basis were $0.17,0.34$ and $0.53 \mathrm{~g} \mathrm{~m}^{-2}$, respectively. For the two southern stations, Majorca $\left(39^{\circ} 15^{\prime} \mathrm{N}\right.$, $\left.3^{\circ} 03^{\prime} \mathrm{E}\right)$ and Lampedusa $\left(35^{\circ} 31^{\prime} \mathrm{N}, 12^{\circ} 37^{\prime} \mathrm{E}\right)$, the maximum weekly deposition fluxes are almost 1 order of magnitude higher, 3.2 and $2.7 \mathrm{~g} \mathrm{~m}^{-2} \mathrm{wk}^{-1}$, respectively. Deposition fluxes for 1-year measurements ranged from $7.4 \mathrm{~g} \mathrm{~m}^{-2}$ year $^{-1}$ in the southern part of the western Mediterranean to $0.9 \mathrm{~g} \mathrm{~m}^{-2}$ year $^{-1}$ at the French northern station. This confirms a strong south-north decreasing gradient of the atmospheric deposition mass flux in the western Mediterranean region. These annual deposition fluxes are significantly lower than those previously measured between the 1980s and early 2000s mainly because only few intense deposition events $\left(>1 \mathrm{~g} \mathrm{~m}^{-2}\right)$ were recorded. These results seem to be in agreement with the decreasing trend of $\mathrm{PM}_{10}$ concentrations over the Mediterranean region and with variation in large-scale atmospheric circulation affecting dust atmospheric contents (lower values of the NAO indices during the last two decades).

We selected the 98 most intense dust deposition events (MIDD) for the investigated period. They occurred preferentially in spring whatever the sampling station. However, the southern stations of the network (Lampedusa and Majorca) exhibit a second maximum in autumn while the northern stations (Corsica, Frioul, Le Casset) exhibit this second maximum in summer. Few dust deposition events were recorded simultaneously on several stations, suggesting that different dust events contribute to the deposition measured in different parts of the western Mediterranean.

By matching satellite observations of MODIS AOD and HYSPLIT air mass trajectories, we defined seven large Saharan dust provenance areas and discussed how they contribute to dust deposition in the western Mediterranean region. The western Sahara is by far the most frequent dust provenance of the intense dust deposition measured in the northern and western part of the western Mediterranean basin. The central and the south-eastern parts of the western basin are equally affected by dust transported from western and eastern Saharan regions. In the same way, we also discussed the main dust transport trajectories leading to the Saharan dust deposition in the different parts of the western Mediterranean. We identified six major dust transport routes. Three of them, corresponding to $70 \%$ of all trajectories, are dominant in spring (one trajectory type, a) and in summer (the other two, c and d).

Finally, we showed that several dust deposition events (DDE) can contribute to high weekly dust deposition fluxes measured in the stations of the network. The daily precipitation measured at the station allowed us to discuss the relative contribution of wet and dry dust deposition to the weekly deposition fluxes. Even if the procedure we used only allows one to roughly estimating wet vs. dry deposition occurrences, the dry deposition can contribute significantly for the highest deposition fluxes (MIDD) to the total deposition, from 10 and $46 \%$ of the total deposited mass depending on the station.

The results show that dust deposition in the western Mediterranean region is far from being homogeneous. A high spatial and temporal variability of the deposition is observed. A south-north decrease of the intensity of the deposition fluxes is noticed. Moreover, during the investigated period, different source regions contribute to the dust deposition in different locations of the central and western Mediterranean in relation with different dust transport pathways. Our results suggest a seasonal pattern of the Saharan high dust deposition within the western Mediterranean basin for the investigated period, which could be refined with longer time series of deposition measurements. This unique data set will be used to test the dust deposition in atmospheric transport models in complement to other aerosols measurements available at the stations.

\section{Data availability}

To obtain the data of the CARAGA network, contact Gilles Bergametti or Benoit Laurent at LISA (http://mistrals. sedoo.fr/Database-Content/?project=ChArMEx).

Acknowledgements. This study was funded by the PRIMEQUALADEME programme on "Pollution atmosphérique longue distance" through the research project "Mesure du dépôt atmosphérique et validation de sa représentation dans les modèles régionaux" (DEMO project, contract no. 0962c0067). This project was also funded by the MISTRALS (Mediterranean Integrated Studies at Local and Regional Scales) programme as part of the Chemistry-Aerosol Mediterranean Experiment (ChArMEx) and by the Spanish Government project ChArMEx: aerosols deposition ref: CTM2011-14036-E. The development of the CARAGA collector was supported both by the Chemistry Faculty of the Paris Diderot University and the PRIMEQUAL-ADEME DEMO project. The authors would like to thank M.-D. Loÿe-Pilot and two anonymous reviewers for their insightful and helpful comments on the manuscript. Terra-and Aqua-MODIS AOD used in this study were produced with the Giovanni online data system, developed and maintained by the NASA Goddard Earth Sciences (GES) Data and Information Services Center (DISC). We thank the HYSPLIT teams for making the backward and forward air mass trajectories available, and EUMETSAT and ICARE for the MSG/SEVIRI products.

Edited by: N. Mihalopoulos

Reviewed by: M.-D. Loÿe-Pilot and two anonymous referees 


\section{References}

Alfaro, S. and Gomes, L.: Modeling mineral aerosol production by wind erosion: Emission intensities and aerosol distributions in source areas, J. Geophys. Res., 106, 18075-18084, 2001.

Avila, A., Queralt-Mitjans, I., and Alarcón, M.: Mineralogical composition of African dust delivered by red rains over northeastern Spain, J. Geophys. Res., 102, 21977-21996, doi:10.1029/97JD00485, 1997.

Avila, A., Alarcón, M., Castillo, S., Escudero, M., Orellana, J. G., Masqué, P., and Querol, X.: Variation of soluble and insoluble calcium in red rains related to dust sources and transport patterns from North Africa to northeastern Spain, J. Geophys. Res., 112, 1-14, doi:10.1029/2006JD007153, 2007.

Barnaba, F. and Gobbi, G. P.: Aerosol seasonal variability over the Mediterranean region and relative impact of maritime, continental and Saharan dust particles over the basin from MODIS data in the year 2001, Atmos. Chem. Phys., 4, 2367-2391, doi:10.5194/acp-4-2367-2004, 2004.

Bergametti, G. and Fôret, G.: Dust deposition, in: Mineral Dust: A Key Player in the Earth System, edited by: Knippertz, P. and Stuut, J.-B. W., 179-200, doi:10.1007/978-94-017-89783_8, Springer, Dordrecht, 2014.

Bergametti, G., Gomes, L., Remoudaki, E., Desbois, M., Martin, D., and Buat-Ménard, P.: Present transport and deposition patterns of African dusts to the north-western Mediterranean, in: Paleometeorology: Modern and Past Patterns of Global Atmospheric Transport, edited by: Leinen, M. and Sarnthein, M., Kluwer, Dordrecht, 227-252, 1989.

Brooks, N. and Legrand, M.: Dust variability over northern Africa and rainfall in the Sahel, in: Linking Land Surface change to climate change, edited by: McLaren, S. J. and Kniveton, D., Kluwer Academic Publishers, Dordrecht, 1-25, 2000.

Cautenet, G., Guillard, F., Marticorena, B., Bergametti, G., Dulac, F., and Edy, J.: Modelling of a Saharan dust event, Meteorol. Z., 9, 221-230, 2000.

Chin, M., Ginoux, P., Kinne, S., Torres, O., Holben, B. N., Duncan, B. N., Martin, R. V., Logan, J. A., Higurashi, A., and Nakajima, T.: Tropospheric aerosol optical thickness from the GOCART model and comparisons with satellite and Sun photometer measurements, J. Atmos. Sci., 59, 461-483, doi:10.1175/15200469(2002)059<0461:TAOTFT>2.0.CO, 2002.

di Iorio, T., di Sarra, A., Sferlazzo, D. M., Cacciani, M., Meloni, D., Monteleone, F., Fuà, D., and Fiocco, G.: Seasonal evolution of the tropospheric aerosol vertical profile in the central Mediterranean and role of desert dust, J. Geophys. Res., 114, D02201, doi:10.1029/2008JD010593, 2009.

di Sarra, A., di Iorio, T., Cacciani, M., Fiocco, G., and Fuà, D.: Saharan dust profiles measured by lidar at Lampedusa, J. Geophys. Res., 106, 10335, doi:10.1029/2000JD900734, 2001.

Draxler, R. R. and Rolph, G. D.: HYSPLIT (HYbrid Single-Particle Lagrangian Integrated Trajectory) Model access via NOAA ARL READY Website, available at: https://ready.arl.noaa.gov/ HYSPLIT.php/, NOAA Air Resources Laboratory, College Park, MD, 2003.

Duce, R. A. and Tindale, N. W.: Atmospheric transport of iron and its deposition in the ocean, Limnol. Oceanogr., 36, 1715-1726, 1991.

Escudero, M., Castillo, S., Querol, X., Avila, A., Alarcón, M., Viana, M. M., Alastuey, A., Cuevas, E., and Rodríguez, S.: Wet and dry African dust episodes over eastern Spain, J. Geophys. Res., 110, D18S08, doi:10.1029/2004JD004731, 2005.

Escudero, M., Stein, A. F., Draxler, R. R., Querol, X., Alastuey, A., Castillo, S., and Avila, A.: Source apportionment for African dust outbreaks over the Western Mediterranean using the HYSPLIT model, Atmos. Res., 99, 518-527, doi:10.1016/j.atmosres.2010.12.002, 2011.

Fiol, L. A., Fornós, J. J., Gelabert, B., and Guijarro, J. A.: Dust rains in Mallorca (western Mediterranean): their occurrence and role in some recent geological processes, Catena, 63, 64-84, doi:10.1016/j.catena.2005.06.012, 2005.

Ganor, E. and Foner, H. A.: Mineral dust concentrations, deposition fluxes and deposition velocities in dust episodes over Israel, J. Geophys. Res., 106, 18431-18437, doi:10.1029/2000JD900535, 2001.

Ginoux, P. and Torres, O.: Empirical TOMS index for dust aerosol: Applications to model validation and source characterization, J. Geophys. Res., 108, 4534, doi:10.1029/2003JD003470, 2003.

Guerzoni, S., Landuzzi, W., Lenaz, R., Quarantotto, G., Rampazzo, G., Molinaroli, E., Turetta, C., Visin, F., Cesari, G., and Cristini, S.: Fluxes of soluble and insoluble metals and nutrients from the atmosphere to the central Mediterranean Sea, Water Poll. Res. Rep., 30, 438-493, 1993.

Guerzoni, S., Molinaroli, E., and Chester, R.: Saharan dust inputs to the western Mediterranean Sea: Depositional patterns, geochemistry and sedimentological implications, Deep.-Sea Res. Pt. II , 44, 631-654, doi:10.1016/S0967-0645(96)00096-3, 1997.

Guerzoni, S., Molinaroli, E., Rossini, P., Rampazzo, G., Quarantotto, G., De Falco, G., and Cristini, S.: Role of desert aerosol in metal fluxes in the Mediterranean area, Chemosphere, 39, 229246, doi:10.1016/S0045-6535(99)00105-8, 1999.

Guieu, C., Loÿe-Pilot, M. D., Ridame, C., and Thomas, C.: Chemical characterization of the Saharan dust end-member: Some biogeochemical implications for the western Mediterranean Sea, J. Geophys. Res., 107, 4258, doi:10.1029/2001JD000582, 2002.

Guieu, C., Loÿe-Pilot, M. D., Benyahya, L., and Dufour, A.: Spatial variability of atmospheric fluxes of metals (Al, Fe, Cd, $\mathrm{Zn}$ and $\mathrm{Pb}$ ) and phosphorus over the whole Mediterranean from a oneyear monitoring experiment: Biogeochemical implications, Mar. Chem., 120, 164-178, doi:10.1016/j.marchem.2009.02.004, 2010.

Hamonou, E., Chazette, P., Balis, D., Dulac, F., Schneider, X., Galani, E., Ancellet, G., and Papayannis, A.: Characterization of the vertical structure of Saharan dust export to the Mediterranean basin, J. Geophys. Res., 104, 22257-22270, doi:10.1029/1999JD900257, 1999.

Holben, B. N., Smirnov, A., Eck, T. F., Slutsker, I., Abuhassan, N., Newcomb, W. W., Schafer, J. S., Chatenet, B., Lavenu, F., Kaufman, Y. J., Vande Castle, J., Setzer, A., Markham, B., Clark, D., Frouin, R., Halthore, R., Karneli, A., O’Neill, N. T., Pietras,C., Pinker, R. T., Voss, K., and Zibordi, G.: An emerging ground-based aerosol climatology - Aerosol optical depth from AERONET, J. Geophys. Res., 106, 12067-12097, 2001.

Huneeus, N., Schulz, M., Balkanski, Y., Griesfeller, J., Prospero, J., Kinne, S., Bauer, S., Boucher, O., Chin, M., Dentener, F., Diehl, T., Easter, R., Fillmore, D., Ghan, S., Ginoux, P., Grini, A., Horowitz, L., Koch, D., Krol, M. C., Landing, W., Liu, X., Mahowald, N., Miller, R., Morcrette, J.-J., Myhre, G., Penner, J., Perlwitz, J., Stier, P., Takemura, T., and Zender, C. S.: Global 
dust model intercomparison in AeroCom phase I, Atmos. Chem. Phys., 11, 7781-7816, doi:10.5194/acp-11-7781-2011, 2011.

Israelevich, P. L.: Annual variations of physical properties of desert dust over Israel, J. Geophys. Res., 108, 1-9, doi:10.1029/2002JD003163, 2003.

Israelevich, P. L., Levin, Z., Joseph, J. H., and Ganor, E.: Desert aerosol transport in the Mediterranean region as inferred from the TOMS aerosol index, J. Geophys. Res.-Atmos., 107, 1-13, doi:10.1029/2001JD002011, 2002.

Jorba, O., Pérez, C., Rocadenbosch, F., and Baldasano, J.: Cluster Analysis of 4-Day Back Trajectories Arriving in the Barcelona Area, Spain, from 1997 to 2002, J. Appl. Meteorol., 43, 887-901, doi:10.1175/1520-0450(2004)043<0887:CAODBT>2.0.CO, 2004.

Kubilay, N., Nickovic, S., Moulin, C., and Dulac, F.: An illustration of the transport and deposition of mineral dust onto the eastern Mediterranean, Atmos. Environ., 34, 1293-1303, doi:10.1016/S1352-2310(99)00179-X, 2000.

Laurent, B., Losno, R., Chevaillier, S., Vincent, J., Roullet, P., Bon Nguyen, E., Ouboulmane, N., Triquet, S., Fornier, M., Raimbault, P., and Bergametti, G.: An automatic collector to monitor insoluble atmospheric deposition: application for mineral dust deposition, Atmos. Meas. Tech., 8, 2801-2811, doi:10.5194/amt8-2801-2015, 2015.

Le Bolloch, O., Guerzoni, S., and Molinaroli, E.: AtmosphereOcean mass fluxes at two coastal sites in Sardinia (39-41 ${ }^{\circ} \mathrm{N}, 8$ $\left.10^{\circ} \mathrm{E}\right)$, in: The Impact of Desert Dust across the Mediterranean, edited by: Guerzoni, S. and Chester, R., Kluwer Academic Publishers, Dordrecht, 217-222, 1996.

Levy, R. C., Mattoo, S., Munchak, L. A., Remer, L. A., Sayer, A. M., Patadia, F., and Hsu, N. C.: The Collection 6 MODIS aerosol products over land and ocean, Atmos. Meas. Tech., 6, 29893034, doi:10.5194/amt-6-2989-2013, 2013.

Loÿe-Pilot, M. D. and Martin, J. M.: Saharan dust input to the western Mediterranean: An eleven years records in Corsica, in: The Impact of Desert Dust across the Mediterranean, edited by: Guerzoni, S. and Chester, R., Kluwer Academic Publishers, Dordrecht, 191-199, 1996.

Loÿe-Pilot, M. D., Martin, J. M., and Morelli, J.: Influence of Saharan dust on the rain acidity and atmospheric input to the Mediterranean, Nature, 321, 427-428, doi:10.1038/321427a0, 1986.

Loÿe-Pilot, M. D., Guieu, C., and Ridame, C.: Atmospheric bulk fluxes of natural and pollutant metals to the north western mediterranean; their trend over the past 15 years (1985-2000), in: Atmospheric Transport and Deposition of Pollutants into the Mediterranean Sea - Final reports on research project, UNEP/MAP Tech. Rep. Ser. No.133, 35-54, United Nations Environment Programme, Athens, 2001.

Marconi, M., Sferlazzo, D. M., Becagli, S., Bommarito, C., Calzolai, G., Chiari, M., di Sarra, A., Ghedini, C., Gómez-Amo, J. L., Lucarelli, F., Meloni, D., Monteleone, F., Nava, S., Pace, G., Piacentino, S., Rugi, F., Severi, M., Traversi, R., and Udisti, R.: Saharan dust aerosol over the central Mediterranean Sea: $\mathrm{PM}_{10}$ chemical composition and concentration versus optical columnar measurements, Atmos. Chem. Phys., 14, 2039-2054, doi:10.5194/acp-14-2039-2014, 2014.

Marticorena, B.: Dust production mechanisms, in: Mineral Dust: A Key Player in the Earth System, edited by: Knippertz, P. and Stuut, J.-B. W., 93-120, doi:10.1007/978-94-017-8978-3_8, Springer, Dordrecht, 2014.

Marticorena, B. and Bergametti, G.: Modeling the atmospheric dust cycle: 1. Design of a soil-derived dust production scheme, J. Geophys. Res., 100, 16415-16430, 1995.

Martin, D., Bergametti, G., and Strauss, B.: On the use of the synoptic vertical velocity in trajectory model: validation by geochemical tracers, Atmos. Environ., 24, 2059-2069, doi:10.1016/09601686(90)90240-N, 1990.

Mattson, J. O. and Nihlén, T.: The transport of Saharan dust to southern Europe: a scenario, J. Arid Environ., 32, 111-119, doi:10.1006/jare.1996.0011, 1994.

Meloni, D., di Sarra, A., di Iorio, T., and Fiocco, G.: Direct radiative forcing of Saharan dust in the Mediterranean from measurements at Lampedusa Island and MISR space-borne observations, J. Geophys. Res.-Atmos., 109, 1-15, doi:10.1029/2003JD003960, 2004.

Meloni, D., di Sarra, A., Monteleone, F., Pace, G., Piacentino, S., and Sferlazzo, D. M.: Seasonal transport patterns of intense Saharan dust events at the Mediterranean island of Lampedusa, Atmos. Res., 88, 134-148, doi:10.1016/j.atmosres.2007.10.007, 2008.

Morales-Baquero, R., Pulido-Villena, E., and Reche, I.: Atmospheric inputs of phosphorus and nitrogen to the southwest Mediterranean region: Biogeochemical responses of high mountain lakes, Limnol. Oceanogr., 51, 830-837, doi:10.4319/lo.2006.51.2.0830, 2006.

Moulin, C., Lambert, C. E., Dulac, F., and Dayan, U.: Control of atmospheric export of dust from North Africa by the North Atlantic Oscillation, Nature, 387, 691-694, doi:10.1038/42679, 1997.

Moulin, C., Lambert, C. E., Dayan, U., Masson, V., Ramonet, M., Bousquet, P., Legrand, M., Balkanski, Y. J., Guelle, W., Marticorena, B., Bergametti, G., and Dulac, F.: Satellite climatology of African dust transport in the Mediterranean atmosphere, J. Geophys. Res., 103, 13137, doi:10.1029/98JD00171, 1998.

Nabat, P., Somot, S., Mallet, M., Chiapello, I., Morcrette, J. J., Solmon, F., Szopa, S., Dulac, F., Collins, W., Ghan, S., Horowitz, L. W., Lamarque, J. F., Lee, Y. H., Naik, V., Nagashima, T., Shindell, D., and Skeie, R.: A 4-D climatology (1979-2009) of the monthly tropospheric aerosol optical depth distribution over the Mediterranean region from a comparative evaluation and blending of remote sensing and model products, Atmos. Meas. Tech., 6, 1287-1314, doi:10.5194/amt-6-1287-2013, 2013.

O’Hara, S. L., Clarke, M. L., and Elatrash, M. S.: Field measurements of desert dust deposition in Libya, Atmos. Environ., 40, 3881-3897, doi:10.1016/j.atmosenv.2006.02.020, 2006.

Pey, J., Querol, X., Alastuey, A., Forastiere, F., and Stafoggia, M.: African dust outbreaks over the Mediterranean Basin during 2001-2011: $\mathrm{PM}_{10}$ concentrations, phenomenology and trends, and its relation with synoptic and mesoscale meteorology, Atmos. Chem. Phys., 13, 1395-1410, doi:10.5194/acp-13-13952013, 2013.

Pongkiatkul, P. and Kim Oanh, N. T.: Assessment of potential long-range transport of particulate air pollution using trajectory modeling and monitoring data, Atmos. Res., 85, 3-17, doi:10.1016/j.atmosres.2006.10.003, 2007.

Prospero, J. M.: Long-term measurements of the transport of African mineral dust to the southeastern United States: Impli- 
cations for regional air quality, J. Geophys. Res., 104, 1591715927, doi:10.1029/1999JD900072, 1999.

Prospero, J. M., Ginoux, P., Torres, O., Nicholson, S. E., and Gill, T. E.: Environmental characterization of global sources of atmospheric soil dust identified with the Nimbus 7 Total Ozone Mapping Spectrometer (TOMS) absorbing aerosol product, Rev. Geophys., 40, 1002, doi:10.1029/2000RG000095, 2002.

Pye, K.: Aeolian dust transport and deposition over Crete and adjacent parts of the Mediterranean Sea, Earth Surf. Proc. Land., 17, 271-288, 1992.

Querol, X., Pey, J., Pandolfi, M., Alastuey, A., Cusack, M., Pérez, N., Moreno, N., Viana, M., Mihalopoulos, N., Kallos, G., and Kleanthous, S.: African dust contributions to mean ambient $\mathrm{PM}_{10}$ mass-levels across the Mediterranean basin, Atmos. Environ., 43, 4266-4277, 2009.

Remer, L. A., Kleidman, R. G., Levy, R. C., Kaufman, Y. J., Tanré, D., Mattoo, S., Martins, J. V., Ichoku, C., Koren, I., Yu, H., and Holben, B. N.: Global aerosol climatology from the MODIS satellite sensors, J. Geophys. Res., 113, D14S07, doi:10.1029/2007JD009661, 2008.

Remoudaki, E.: Etude des processus contrôlant la variabilité temporelle des flux atmosphériques de polluants et de poussières minérales en Méditerranée occidentale, Thèse de doctorat, Univ. Paris 7, 244 pp., 1990.

Ridame, C., Guieu, C., and Loÿe-Pilot, M.-D.: Trend in total atmospheric fluxes of aluminium, iron and trace metals in the northwestern Mediterranean over the past decade (1985-1997), J. Geophys. Res., 104, 30127-30138, doi:10.1029/1999JD900747, 1999.

Salvador, P., Alonso-Pérez, S., Pey, J., Artíñano, B., de Bustos, J. J., Alastuey, A., and Querol, X.: African dust outbreaks over the western Mediterranean Basin: 11-year characterization of atmospheric circulation patterns and dust source areas, Atmos. Chem. Phys., 14, 6759-6775, doi:10.5194/acp-14-6759-2014, 2014.

Scheifinger, H. and Kaiser, A.: Validation of trajectory statistical methods, Atmos. Environ., 41, 8846-8856, 2007.

Schepanski, K., Tegen, I., Laurent, B., Heinold, B., and Macke, A.: A new Saharan dust source activation frequency map derived from MSG-SEVIRI IR-channels, Geophys. Res. Lett., 34, 1-5, doi:10.1029/2007GL030168, 2007.

Schepanski, K., Tegen, I., and Macke, A., Comparison of satellite based observations of Saharan dust source areas, Remote Sens. Environ., 123, 90-97, 2012.

Schulz, M., Prospero, J. M., Baker, A. R., Dentener, F., Ickes, L., Liss, P. S., Mahowald, N., Nickovic, S., Perez García-Pando, C., Rodríguez, S., Manmohan Sarin, O., Tegen, I., and Duce, R. A.: Atmospheric transport and deposition of mineral dust to the ocean: implications for research needs. Environ. Sci. Technol., 46, 10390-10404, 2012.

Sciare, J., Oikonomou, K., Cachier, H., Mihalopoulos, N., Andreae, M. O., Maenhaut, W., and Sarda-Estève, R.: Aerosol mass closure and reconstruction of the light scattering coefficient over the Eastern Mediterranean Sea during the MINOS campaign, Atmos. Chem. Phys., 5, 2253-2265, doi:10.5194/acp-5-2253-2005, 2005.

Shao, Y.: Simplification of a dust emission scheme and comparison with data, J. Geophys. Res., 109, D10202, doi:10.1029/2003JD004372, 2004.
Shao, Y., Raupach, M. R., and Findlater, P. A.: Effect of saltation bombardment on the entrainment of dust by wind, J. Geophys. Res., 98, 12719-12726, 1993.

Sheldon, R. W.: Size separation of marine seston by membrane and glass-fiber filters, Limnol. Oceanogr., 17, 494-498, 1972.

Shi, T. and Cressie, N.: Global statistical analysis of MISR aerosol data: a massive data product from NASA's Terra satellite, Environmetrics, 18, 665-680, 2007.

Smirnov, A., Holben, B. N., Giles, D. M., Slutsker, I., O’Neill, N. T., Eck, T. F., Macke, A., Croot, P., Courcoux, Y., Sakerin, S. M., Smyth, T. J., Zielinski, T., Zibordi, G., Goes, J. I., Harvey, M. J., Quinn, P. K., Nelson, N. B., Radionov, V. F., Duarte, C. M., Losno, R., Sciare, J., Voss, K. J., Kinne, S., Nalli, N. R., Joseph, E., Krishna Moorthy, K., Covert, D. S., Gulev, S. K., Milinevsky, G., Larouche, P., Belanger, S., Horne, E., Chin, M., Remer, L. A., Kahn, R. A., Reid, J. S., Schulz, M., Heald, C. L., Zhang, J., Lapina, K., Kleidman, R. G., Griesfeller, J., Gaitley, B. J., Tan, Q., and Diehl, T. L.: Maritime aerosol network as a component of AERONET - first results and comparison with global aerosol models and satellite retrievals, Atmos. Meas. Tech., 4, 583-597, doi:10.5194/amt-4-583-2011, 2011.

Stohl, A.: Computation, accuracy and applications of trajectories a review and bibliography, Atmos. Environ., 32, 947-966, 1998.

Ternon, E., Guieu, C., Loÿe-Pilot, M.-D., Leblond, N., Bosc, E., Gasser, B., Miquel, J.-C., and Martín, J.: The impact of Saharan dust on the particulate export in the water column of the North Western Mediterranean Sea, Biogeosciences, 7, 809-826, doi:10.5194/bg-7-809-2010, 2010.

Textor, C., Schulz, M., Guibert, S., Kinne, S., Balkanski, Y., Bauer, S., Berntsen, T., Berglen, T., Boucher, O., Chin, M., Dentener, F., Diehl, T., Easter, R., Feichter, H., Fillmore, D., Ghan, S., Ginoux, P., Gong, S., Grini, A., Hendricks, J., Horowitz, L., Huang, P., Isaksen, I., Iversen, I., Kloster, S., Koch, D., Kirkevåg, A., Kristjansson, J. E., Krol, M., Lauer, A., Lamarque, J. F., Liu, X., Montanaro, V., Myhre, G., Penner, J., Pitari, G., Reddy, S., Seland, Ø., Stier, P., Takemura, T., and Tie, X.: Analysis and quantification of the diversities of aerosol life cycles within AeroCom, Atmos. Chem. Phys., 6, 1777-1813, doi:10.5194/acp-6-1777-2006, 2006.

Torres, O., Bhartia, P. K., Herman, J. R., Sinyuk, A., Ginoux, P., and Holben, B.: A long-term record of aerosol optical depth from TOMS observations and comparison to AERONET measurements, J. Atmos. Sci., 59, 398-413, 2002.

Usero, J. and Gracia, I.: Trace and major elements in atmospheric deposition in the "Campo de Gibraltar" region, Atmos. Environ., 20, 1639-1646, doi:10.1016/0004-6981(86)90254-4, 1986.

Washington, R., Todd, M., Middleton, N. J., and Goudie, A. S.: Dust-storm source areas determined by the total ozone monitoring spectrometer and surface observations, Ann. Assoc. Am. Geogr., 93, 297-313, 2003.

Zender, C. S., Miller, R. L. R. L., and Tegen, I.: Quantifying mineral dust mass budgets: Terminology, constraints, and current estimates, Eos T. Am. Geophys. Un., 85, 509-512, 2004. 